\title{
The Remarkable Impacts of Gordon Life Science Institute
}

\section{Kuo-Chen Chou}

Gordon Life Science Institute, Boston, Massachusetts 02478, United States of America

Correspondence to: Kuo-Chen Chou, kcchou@gordonlifescience.org, kcchou38@gmail.com

Keywords: Internet Institute, Door-Opening Policy, Mankind Common Benefit, Epidemic-Controlling, Economy-Booming Stimulus

Received: February 15, 2021

Accepted: March 15, 2021

Published: March 18, 2021

Copyright $\odot 2021$ by author(s) and Scientific Research Publishing Inc.

This work is licensed under the Creative Commons Attribution International License (CC BY 4.0).

http://creativecommons.org/licenses/by/4.0/

\section{(c) (1) Open Access}

\section{ABSTRACT}

In this review paper, the remarkable impacts of the first Internet Institute, the Gordon Life Science Institute, as well as its profound and far-reaching influence have been systematically and comprehensively presented.

\section{INTRODUCTION}

Founded by Professor Dr. Kuo-Chen Chou, the Gordon Life Science Institute is the first internet institute ever established in the world. It is instructive and intrigued to briefly recall a story.

Because the subtle relation with his own mother and Buddha, Mao Zedong, the dictator and head of Chinese Communist party, had completely closed China's door from 1949 to 1976, seriously hurting China's economy development. Fortunately, things were changed. After the "Cultural Revolution" developed by Mao Zedong had been smashed, China had was under the leadership of Deng Xiaoping, who had clearly pointed out, "open up its door" would be the key and foundation for China's economic development. Ever since then, China has been starting economically expanding, and has become the second richest country next to USA only.

\section{GROWING-UP AND STRONGLY ESTABLISHED}

As a consequence of the "door open" policy and practice, Prof. Dr. Chou was invited by Professor Sture Forsén, the then "Chairman of Nobel Prize Committee", to work in Chemical Center of Lund University as a Visiting Professor. It was very difficult for Swedish people to pronounce "Kuo-Chen Chou". In order for his Swedish colleagues and friends easier to call his name, Prof. Dr. Chou changed "Gordon" as his name in Sweden. In 2003, about 25 years later, the same name was used for the Institute, meaning that Deng Xiaoping's policy can stimulate a lot of great creativities, as indicated by the enormous achievements [1-520].

\section{SOME FACTS AND THEIR IMPLICATIONS}

The Institute has achieved many fruits in science. Listed below are just a few. 
1) Graphical rules for enzyme-catalyzed rate laws.

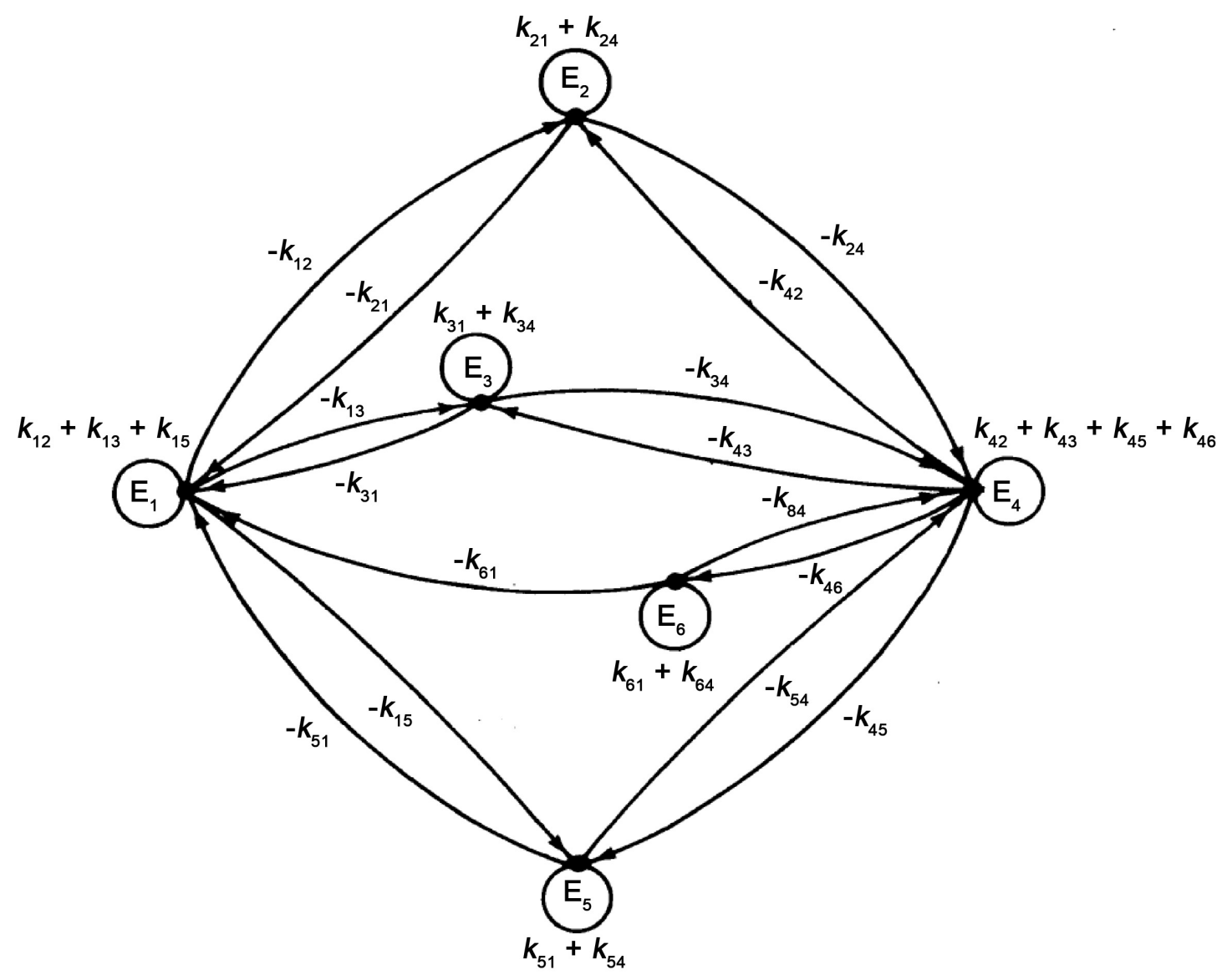

Figure 1. Adapted from [521] with permission.

2) The biological functions of low-frequency phonons.
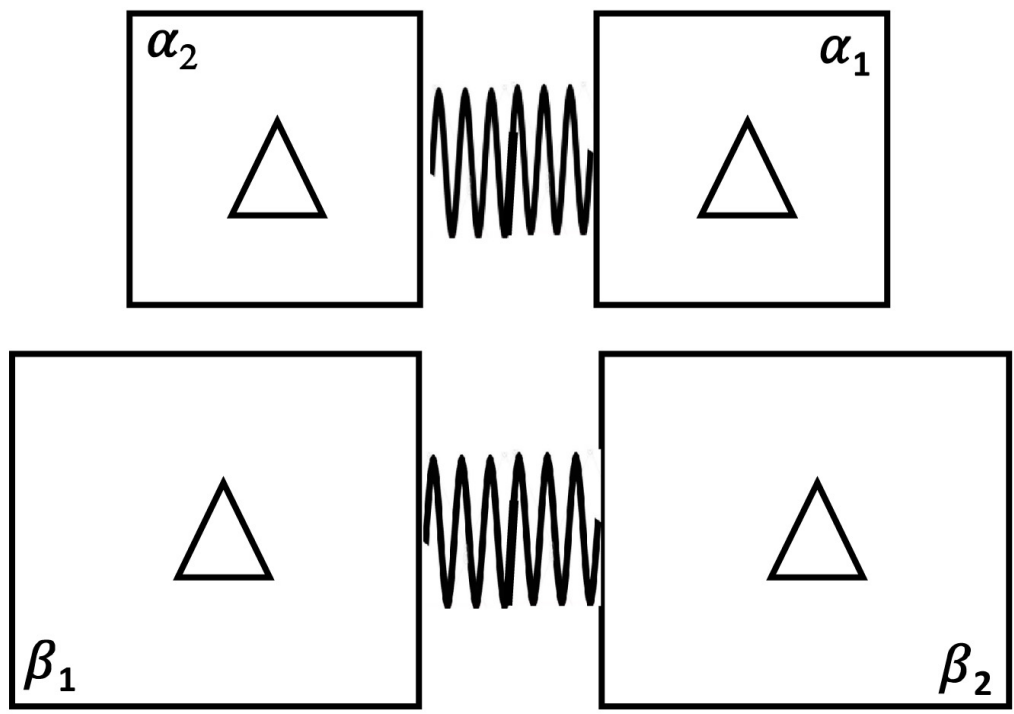

Figure 2. Adapted from [4] with permission. 
3) Diffusion-Controlled Reactions of Enzymes.

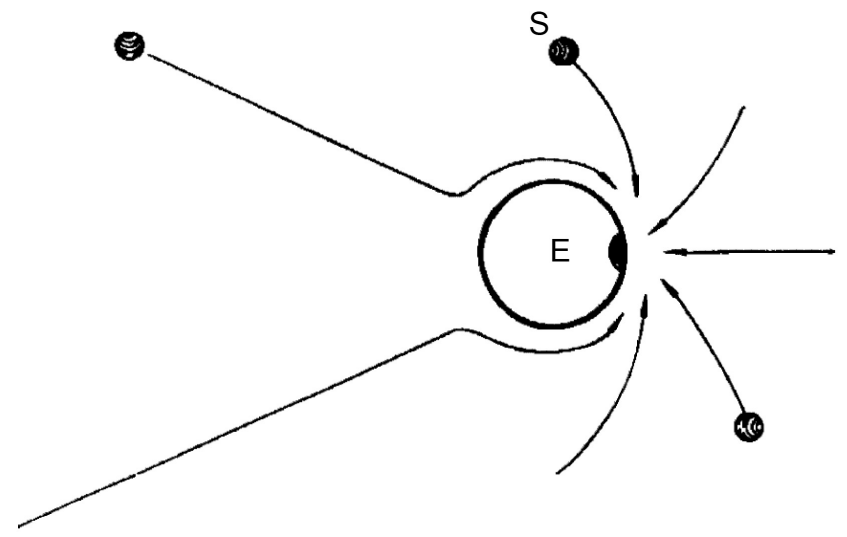

Figure 3. Adapted from [522] with permission.

4) The origin of the right-handed twist of beta-sheets.

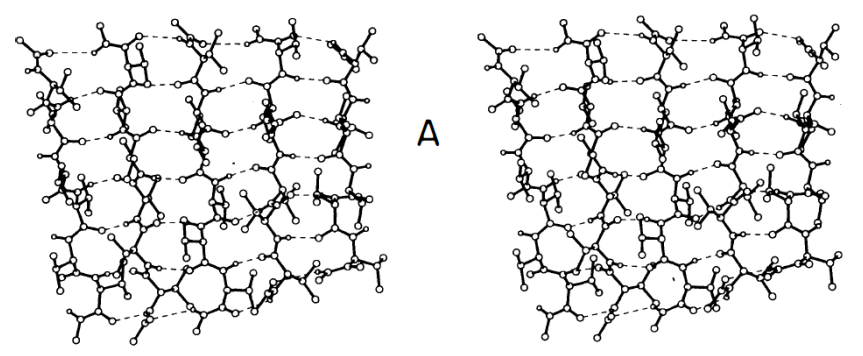

Figure 4. Adapted from [524] with permission.

5) Energetics of Multihelix Interactions in Protein

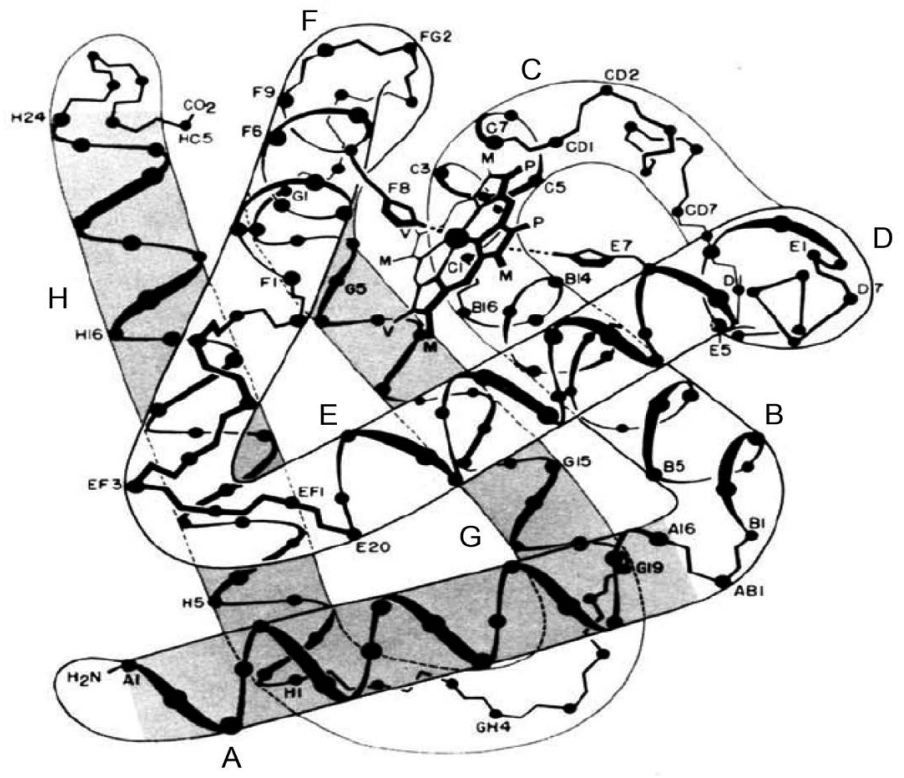

Figure 5. Adapted from [548] with permission. 
6) Study of the Cavity-Active-Site of Enzymes.

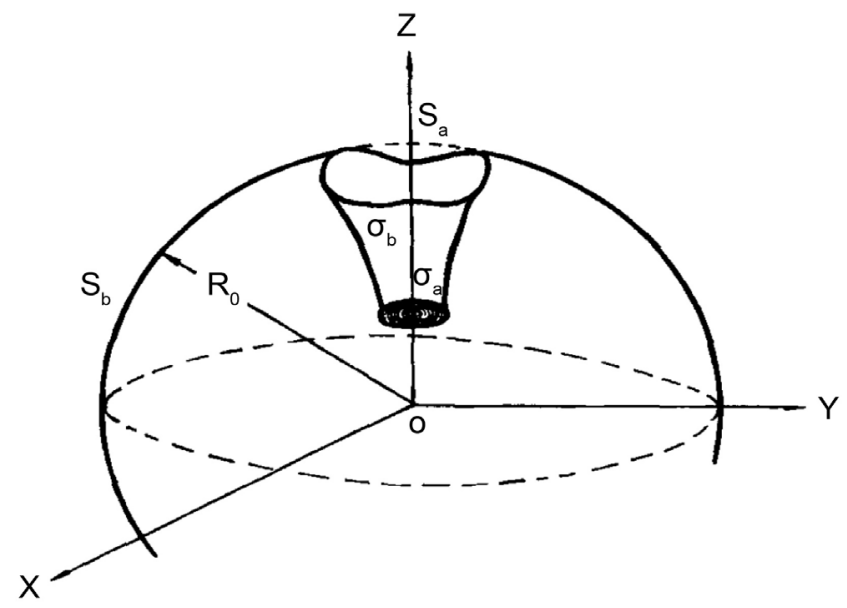

Figure 6. Adapted from [74], with permission.

7) Prediction of membrane protein types and subcellular locations.

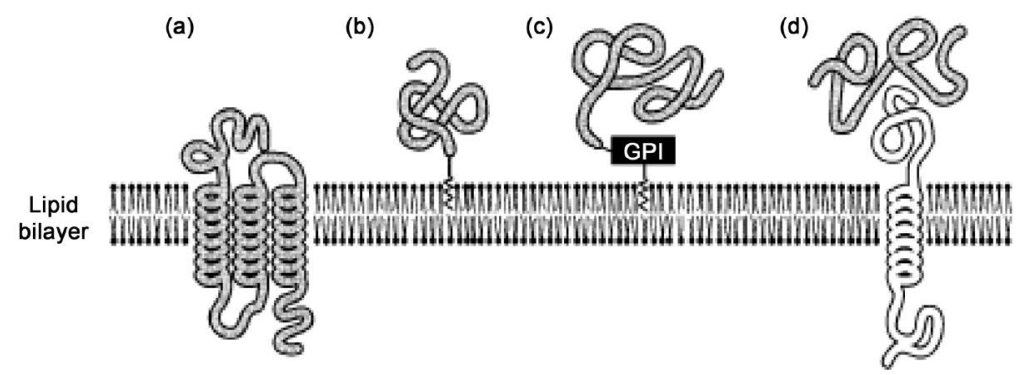

Figure 7. Adapted from [84] with permission.

8) Binding mechanism of coronavirus main proteinase with ligands and its implication to drug design against SARS.

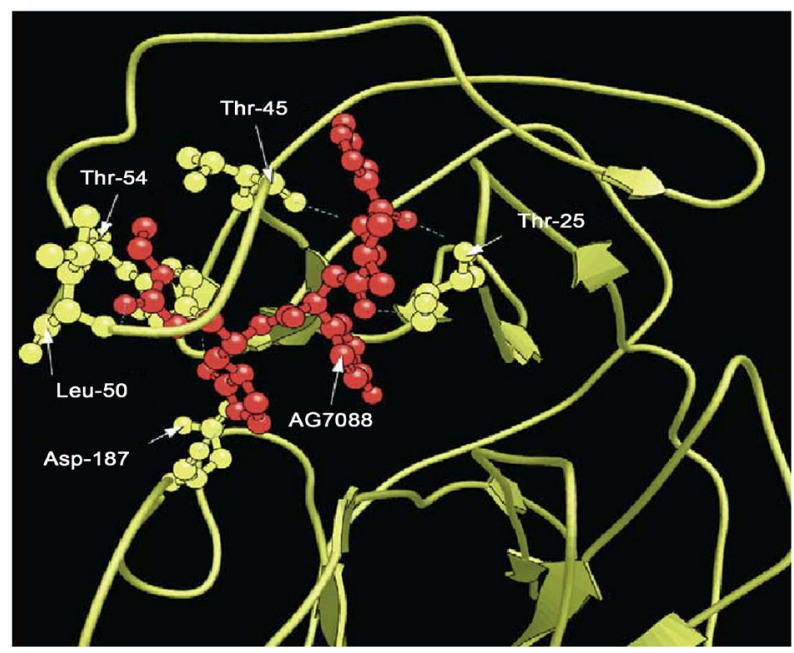

Figure 8. Adapted from [102] with permission. 
9) Identify HIV protease cleavage site.

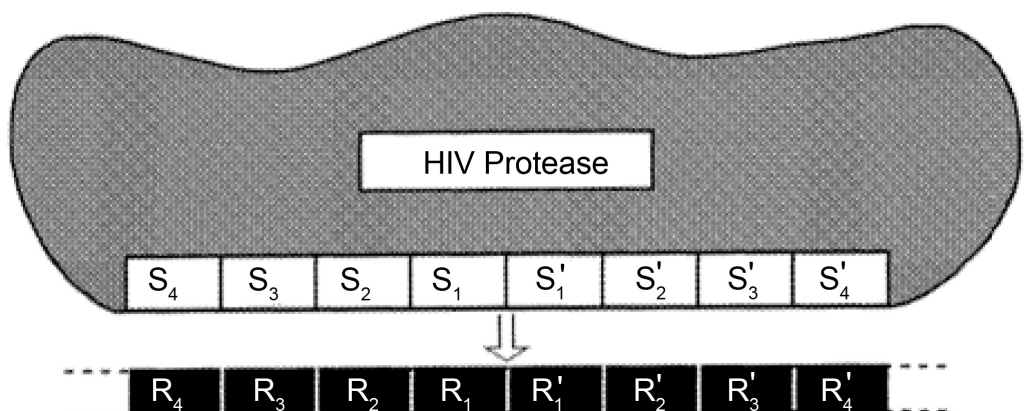

Figure 9. Adapted from [58] with permission.

10) Propose pseudo amino acid composition.

(a)

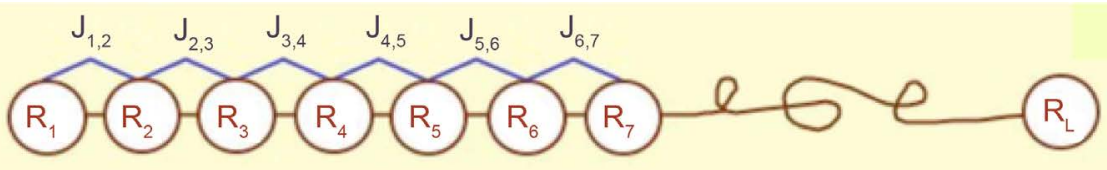

(b)

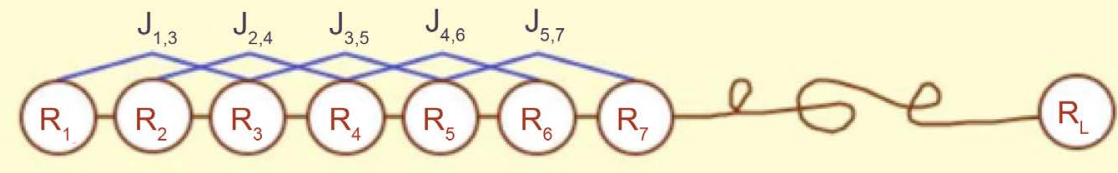

(c)

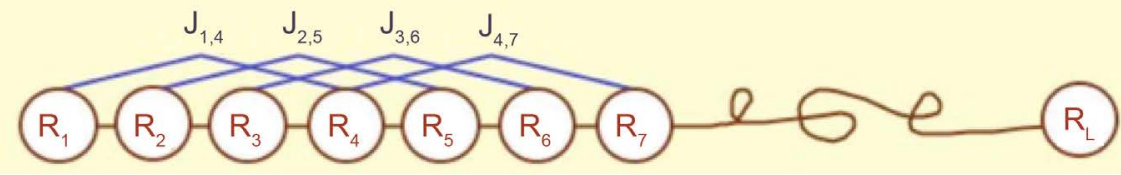

Figure 10. Adapted from [217] with permission.

Proposing the 5-steps rule [418, 419, 422, 502, 525-548].

\section{CONCLUSIVE REMARKS}

It is really awesome and amazing for the Internet Institute to achieve such great achievements during so short period of time, fully indicating "the community with a shared future for mankind” (i.e., “人类命 运共同体”), the philosophy of Xi Jinping is indeed very wise. Particularly, the internet institute is working in different countries or areas, and it is very useful to deal with epidemic (see, e.g., [513, 516, 520]). Up to March 2019, the Institute has 26 members. Among them, 5 have been selected by Thompson Reuter and Clarivate Analytics as the "Highly Cited Researcher". Accordingly, it would not be surprised to see that five members of Gordon Life Scientist have been selected by Clarivate Analytics as Highly Cited Researcher (HCR) (https://hcr.clarivate.com/resources/archived-lists/), indicating that, based on the ratio of HCR per member, the "Gordon Life Science Institute" is far beyond the reach of the "Broad Institute of Harvard and MIT", becoming the very top in the world.

It is anticipated that more remarkable and fantastic accomplishments will be achieved by the Gordon Life Science Institute for many years to come. 


\section{CONFLICTS OF INTEREST}

The author declares no conflicts of interest regarding the publication of this paper.

\section{REFERENCES}

1. K.C. Chou, Two new schematic rules for rate laws of enzyme-catalyzed reactions, J. Theor. Biol., 89 (1981) 581-592.

2. K.C. Chou, A new graphical rule for rate laws of enzyme reactions with branched pathways, Canadian Journal of Biochemistry, 59 (1981) 757-761.

3. K.C. Chou, R.E. Carter, S. Forsen, A new graphical method for deriving rate equations for complicated mechanisms, Chemica Scripta, 18 (1981) 82-86.

4. K.C. Chou, N.Y. Chen, S. Forsen, The biological functions of low-frequency phonons: 2. Cooperative effects, Chemica Scripta, 18 (1981) 126-132.

5. K.C. Chou, S. Forsen, Graphical rules of steady-state reaction systems, Can. J. Chem., 59 (1981) 737-755.

6. K.C. Chou, T.T. Li, G.Q. Zhou, A semi-analytical expression for the concentration distribution of substrate molecules in fast, enzyme-catalyzed reaction systems, Biochim. Biophys. Acta, 657 (1981) 304-308.

7. K.C. Chou, W.M. Liu, Graphical rules for non-steady state enzyme kinetics, J. Theor. Biol., 91 (1981) 637-654.

8. K.C. Chou, G.P. Zhou, Role of the protein outside active site on the diffusion-controlled reaction of enzyme, Journal of American Chemical Society, 104 (1982) 1409-1413.

9. K.C. Chou, Advances in graphical methods of enzyme kinetics, Biophysical Chemistry, 17 (1983) 51-55.

10. K.C. Chou, Low-frequency vibrations of helical structures in protein molecules, Biochem. J., 209 (1983) 573-580.

11. K.C. Chou, Identification of low-frequency modes in protein molecules, Biochem. J., 215 (1983) 465-469.

12. H.M. Sobell, A. Baberjee, E.D. Lozansky, G.P. Zhou, K.C. Chou, The role of low frequency (acoustic) phonons in etermining the premelting and melting behaviors of DNA, Structure and Dynamics: Nucleic Acids and Proteins (Eds. Clementi, E. and Sarma, R.H.), Adenine Press, New York, 1983, pp. 181-195.

13. K.C. Chou, Biological functions of low-frequency vibrations (phonons). 3. Helical structures and microenvironment, Biophys. J., 45 (1984) 881-889.

14. K.C. Chou, The biological functions of low-frequency phonons. 4. Resonance effects and allosteric transition, Biophysical Chemistry, 20 (1984) 61-71.

15. K.C. Chou, Low-frequency vibrations of DNA molecules, Biochem. J., 221 (1984) 27-31.

16. K.C. Chou, Low-frequency motions in protein molecules: beta-sheet and beta-barrel, Biophys. J., 48 (1985) 289-297.

17. K.C. Chou, Prediction of a low-frequency mode in bovine pancreatic trypsin inhibitor molecule, International Journal of Biological Macromolecules, 7 (1985) 77-80.

18. K.C. Chou, Y.S. Kiang, The biological functions of low-frequency phonons: 5. A phenomenological theory, Biophysical Chemistry, 22 (1985) 219-235.

19. K.C. Chou, Origin of low-frequency motion in biological macromolecules: A view of recent progress of quasi-continuity model, Biophysical Chemistry, 25 (1986) 105-116.

20. K.C. Chou, The biological functions of low-frequency phonons: 6. A possible dynamic mechanism of allosteric transition in antibody molecules, Biopolymers, 26 (1987) 285-295.

21. K.C. Chou, Review: Low-frequency collective motion in biomacromolecules and its biological functions, Bio- 
physical Chemistry, 30 (1988) 3-48.

22. K.C. Chou, Graphic rules in steady and non-steady enzyme kinetics, J. Biol. Chem., 264 (1989) 12074-12079.

23. K.C. Chou, Low-frequency resonance and cooperativity of hemoglobin, Trends Biochem. Sci., 14 (1989) 212-213.

24. L. Carlacci, K.C. Chou, Monte Carlo method applied in the search for low energy conformations of ßaßaß structures, Biopolymers, 30 (1990) 135-150.

25. L. Carlacci, K.C. Chou, Energetic approach to the folding of four a-helices connected sequentially, Protein Eng., 3 (1990) 509-514.

26. K.C. Chou, Review: Applications of graph theory to enzyme kinetics and protein folding kinetics. Steady and non-steady state systems, Biophysical Chemistry, 35 (1990) 1-24.

27. K.C. Chou, L. Carlacci, G.M. Maggiora, Conformational and geometrical properties of idealized beta-barrels in proteins, J. Mol. Biol., 213 (1990) 315-326.

28. K.C. Chou, A. Heckel, G. Nemethy, S. Rumsey, L. Carlacci, H.A. Scheraga, Energetics of the structure and chain tilting of antiparallel beta-barrels in proteins, Proteins: Struct., Funct., Genet., 8 (1990) 14-22.

29. L. Carlacci, K.C. Chou, New development on energetic approach to the packing in proteins, J. Comput. Chem., 12 (1991) 410-415.

30. L. Carlacci, K.C. Chou, G.M. Maggiora, A heuristic approach to predicting the tertiary structure of bovine somatotropin, Biochemistry, 30 (1991) 4389-4398.

31. L. Carlacci, M. Schultz, K.C. Chou, Geometric and energy parameters in lysine-retinal chromophores, Protein Eng., 4 (1991) 885-889.

32. K.C. Chou, L. Carlacci, Simulated annealing approach to the study of protein structures, Protein Eng., 4 (1991) 661-667.

33. K.C. Chou, L. Carlacci, Energetic approach to the folding of alpha/beta barrels, Proteins: Struct., Funct., Genet., 9 (1991) 280-295.

34. K.C. Chou, Energy-optimized structure of antifreeze protein and its binding mechanism, J. Mol. Biol., 223 (1992) 509-517.

35. K.C. Chou, L. Carlacci, G.M. Maggiora, L.A. Parodi, M.W. Schultz, An energy-based approach to packing the 7-helix bundle of bacteriorhodopsin, Protein Science, 1 (1992) 810-827.

36. K.C. Chou, C.T. Zhang, A correlation coefficient method to predicting protein structural classes from amino acid compositions, Eur. J. Biochem., 207 (1992) 429-433.

37. K.C. Chou, C.T. Zhang, Diagrammatization of codon usage in $339 \mathrm{HIV}$ proteins and its biological implication, AIDS Research and Human Retroviruses, 8 (1992) 1967-1976.

38. K.C. Chou, C. Zheng, Strong electrostatic loop-helix interactions in bundle motif protein structures, Biophys. J., 63 (1992) 682-688.

39. C.T. Zhang, K.C. Chou, An optimization approach to predicting protein structural class from amino acid composition, Protein Science, 1 (1992) 401-408.

40. K.C. Chou, Conformational change during photocycle of bacteriorhodopsin and its proton-pumping mechanism, J. Protein Chem., 12 (1993) 337-350.

41. K.C. Chou, A vectorized sequence-coupling model for predicting HIV protease cleavage sites in proteins, J. Biol. Chem., 268 (1993) 16938-16948.

42. K.C. Chou, Mini Review: Prediction of protein folding types from amino acid composition by correlation an- 
gles, Amino Acids, 6 (1993) 231-246.

43. K.C. Chou, Graphic rule for non-steady-state enzyme kinetics and protein folding kinetics, Journal of Mathematical Chemistry, 12 (1993) 97-108.

44. K.C. Chou, C.T. Zhang, A new approach to predicting protein folding types, J. Protein Chem., 12 (1993) 169-178.

45. K.C. Chou, C.T. Zhang, F.J. Kezdy, A vector approach to predicting HIV protease cleavage sites in proteins, Proteins: Struct., Funct., Genet., 16 (1993) 195-204.

46. K.C. Chou, Mini Review: A molecular piston mechanism of pumping protons by bacteriorhodopsin, Amino Acids, 7 (1994) 1-17.

47. K.C. Chou, F.J. Kezdy, F. Reusser, Review: Kinetics of processive nucleic acid polymerases and nucleases, Anal. Biochem., 221 (1994) 217-230.

48. K.C. Chou, C.T. Zhang, Predicting protein folding types by distance functions that make allowances for amino acid interactions, J. Biol. Chem., 269 (1994) 22014-22020.

49. K.C. Chou, C.T. Zhang, G.M. Maggiora, Solitary wave dynamics as a mechanism for explaining the internal motion during microtubule growth, Biopolymers, 34 (1994) 143-153.

50. K.C. Chou, Does the folding type of a protein depend on its amino acid composition? FEBS Lett., 363 (1995) 127-131.

51. K.C. Chou, A sequence-coupled vector-projection model for predicting the specificity of GalNAc-transferase, Protein Science, 4 (1995) 1365-1383.

52. K.C. Chou, The convergence-divergence duality in lectin domains of the selectin family and its implications, FEBS Lett., 363 (1995) 123-126.

53. K.C. Chou, C.T. Zhang, Review: Prediction of protein structural classes, Crit. Rev. Biochem. Mol. Biol., 30 (1995) 275-349.

54. K.C. Chou, C.T. Zhang, F.J. Kezdy, R.A. Poorman, A vector projection method for predicting the specificity of GalNAc-transferase, Proteins: Struct., Funct., Genet., 21 (1995) 118-126.

55. C.T. Zhang, K.C. Chou, G.M. Maggiora, Predicting protein structural classes from amino acid composition: application of fuzzy clustering, Protein Eng., 8 (1995) 425-435.

56. K.C. Chou, Review: Prediction of human immunodeficiency virus protease cleavage sites in proteins, Anal. Biochem., 233 (1996) 1-14.

57. K.C. Chou, Knowledge-based model building of tetiary structures for lectin domains of the selectin family, J. Protein Chem., 15 (1996) 161-168.

58. K.C. Chou, A.L. Tomasselli, I.M. Reardon, R.L. Heinrikson, Predicting HIV protease cleavage sites in proteins by a discriminant function method, Proteins: Struct., Funct., Genet., 24 (1996) 51-72.

59. K.C. Chou, C.T. Zhang, D.W. Elrod, Do antisense proteins exist?, J. Protein Chem., 15 (1996) 59-61.

60. G.M. Maggiora, C.T. Zhang, K.C. Chou, D.W. Elrod, Combining fuzzy clustering and neural networks to predict protein structural classes, in: J. Devillers (Ed.) in Neural Networks in QSAR and Drug Design, Academic Press, London, 1996, pp. 255-279.

61. K.C. Chou, Prediction of beta-turns in proteins, Journal of Peptide Research, 49 (1997) 120-144.

62. K.C. Chou, Prediction and classification of alpha-turn types, Biopolymers, 42 (1997) 837-853.

63. K.C. Chou, J.R. Blinn, Classification and prediction of beta-turn types, J. Protein Chem., 16 (1997) 575-595.

64. K.C. Chou, R.L. Heinrikson, Prediction of the tertiary structure of the complement control protein module, J. 
Protein Chem., 16 (1997) 765-773.

65. K.C. Chou, D. Jones, R.L. Heinrikson, Prediction of the tertiary structure and substrate binding site of caspase-8, FEBS Lett., 419 (1997) 49-54.

66. K.C. Chou, C.T. Zhang, G.M. Maggiora, Disposition of amphiphilic helices in heteropolar environments, Proteins: Struct., Funct., Genet., 28 (1997) 99-108.

67. Y.D. Cai, H. Yu, K.C. Chou, Using neural network for prediction of HIV protease cleavage sites in proteins, J. Protein Chem., 17 (1998) 607-615.

68. K.C. Chou, D.W. Elrod, Using discriminant function for prediction of subcellular location of prokaryotic proteins, Biochem Biophys Res Commun (BBRC), 252 (1998) 63-68.

69. K.C. Chou, W. Liu, G.M. Maggiora, C.T. Zhang, Prediction and classification of domain structural classes, Proteins: Struct., Funct., Genet., 31 (1998) 97-103.

70. K.C. Chou, G.M. Maggiora, Domain structural class prediction, Protein Eng., 11 (1998) 523-538.

71. W. Liu, K.C. Chou, Prediction of protein structural classes by modified Mahalanobis discriminant algorithm, J. Protein Chem., 17 (1998) 209-217.

72. K.C. Chou, A key driving force in determination of protein structural classes, Biochemical and Biophysical Research Communications (BBRC), 264 (1999) 216-224.

73. K.C. Chou, D.W. Elrod, Protein subcellular location prediction, Protein Eng., 12 (1999) 107-118.

74. K.C. Chou, D.W. Elrod, Prediction of membrane protein types and subcellular locations, Proteins: Struct., Funct., Genet., 34 (1999) 137-153.

75. K.C. Chou, K.D. Watenpaugh, R.L. Heinrikson, A Model of the complex between cyclin-dependent kinase 5 (Cdk5) and the activation domain of neuronal Cdk5 activator, Biochemical \& Biophysical Research Communications (BBRC), 259 (1999) 420-428.

76. W. Liu, K.C. Chou, Protein secondary structural content prediction, Protein Eng., 12 (1999) 1041-1050.

77. Y.D. Cai, Y.X. Li, K.C. Chou, Using neural networks for prediction of domain structural classes, BBA, 1476 (2000) 1-2.

78. K.C. Chou, Review: Prediction of protein structural classes and subcellular locations, Current Protein and Peptide Science, 1 (2000) 171-208.

79. K.C. Chou, Review: Prediction of tight turns and their types in proteins, Anal. Biochem., 286 (2000) 1-16.

80. K.C. Chou, Prediction of protein subcellular locations by incorporating quasi-sequence-order effect, Biochem Biophys Res Comm (BBRC), 278 (2000) 477-483.

81. K.C. Chou, A.G. Tomasselli, R.L. Heinrikson, Prediction of the Tertiary Structure of a Caspase-9/Inhibitor Complex, FEBS Lett., 470 (2000) 249-256.

82. K.C. Chou, Prediction of protein signal sequences and their cleavage sites, Proteins: Struct., Funct., Genet., 42 (2001) 136-139.

83. K.C. Chou, Using subsite coupling to predict signal peptides, Protein Eng., 14 (2001) 75-79.

84. K.C. Chou, Prediction of protein cellular attributes using pseudo amino acid composition, PROTEINS: Structure, Function, and Genetics (Erratum: ibid., 2001, Vol.44, 60), 43 (2001) 246-255.

85. K.C. Chou, Prediction of signal peptides using scaled window, Peptides, 22 (2001) 1973-1979.

86. Y.D. Cai, X.J. Liu, X.B. Xu, K.C. Chou, Support vector machines for prediction of protein subcellular location by incorporating quasi-sequence-order effect, J. Cell. Biochem., 84 (2002) 343-348.

87. Y.D. Cai, X.J. Liu, X.B. Xu, K.C. Chou, Prediction of protein structural classes by support vector machines, 
Comput. Chem., 26 (2002) 293-296.

88. Y.D. Cai, X.J. Liu, X.B. Xu, K.C. Chou, Support vector machines for predicting the specificity of GalNAc-transferase, Peptides, 23 (2002) 205-208.

89. Y.D. Cai, X.J. Liu, X.B. Xu, K.C. Chou, SVM for predicting membrane protein types by incorporating quasi-sequence-order effect., Internet Electronic Journal of Molecular Design, 1 (2002) 219-226.

90. K.C. Chou, A new branch of proteomics: prediction of protein cellular attributes, in: P.W. Weinrer, Q. Lu (Eds.) Gene Cloning \& Expression Technologies, Chapter 4, pp.57-70, Eaton Publishing, Westborough, MA, 2002, pp. 57-70.

91. K.C. Chou, Review: Prediction of protein signal sequences, Current Protein and Peptide Science, 3 (2002) 615-622.

92. K.C. Chou, D.W. Elrod, Bioinformatical analysis of G-protein-coupled receptors, Journal of Proteome Research, 1 (2002) 429-433.

93. K.C. Chou, W.J. Howe, Prediction of the tertiary structure of the beta-secretase zymogen, Biochem. Biophys. Res. Commun (BBRC), 292 (2002) 702-708.

94. D.W. Elrod, K.C. Chou, A study on the correlation of G-protein-coupled receptor types with amino acid composition, Protein Eng., 15 (2002) 713-715.

95. J. Zhang, C.H. Luan, K.C. Chou, G.V.W. Johnson, Identification of the N-terminal functional domains of Cdk5 by molecular truncation and computer modeling, Proteins: Struct., Funct., Genet., 48 (2002) 447-453.

96. Y.D. Cai, K.C. Chou, Nearest neighbour algorithm for predicting protein subcellular location by combining functional domain composition and pseudo amino acid composition, Biochem Biophys Res Comm (BBRC), 305 (2003) 407-411.

97. Y.D. Cai, S. Lin, K.C. Chou, Support vector machines for prediction of protein signal sequences and their cleavage sites, Peptides, 24 (2003) 159-161.

98. Y.D. Cai, G.P. Zhou, K.C. Chou, Support vector machines for predicting membrane protein types by using functional domain composition, Biophys. J., 84 (2003) 3257-3263.

99. K.C. Chou, Y.D. Cai, Predicting protein quaternary structure by pseudo amino acid composition, Proteins: Struct., Funct., Genet., 53 (2003) 282-289.

100. K.C. Chou, Y.D. Cai, Prediction and classification of protein subcellular location: sequence-order effect and pseudo amino acid composition, Journal of Cellular Biochemistry (Addendum, ibid. 2004, 91, 1085), 90 (2003) 1250-1260.

101. K.C. Chou, D.W. Elrod, Prediction of enzyme family classes, Journal of Proteome Research, 2 (2003) 183-190.

102. K.C. Chou, D.Q. Wei, W.Z. Zhong, Binding mechanism of coronavirus main proteinase with ligands and its implication to drug design against SARS. (Erratum: ibid., 2003, Vol.310, 675), Biochem Biophys Res Comm (BBRC), 308 (2003) 148-151.

103. Q.S. Du, D.Q. Wei, K.C. Chou, Correlation of amino acids in proteins, Peptides, 24 (2003) 1863-1869.

104. Y.D. Cai, R. Pong-Wong, K. Feng, J.C.H. Jen, K.C. Chou, Application of SVM to predict membrane protein types, J. Theor. Biol., 226 (2004) 373-376.

105. Y.D. Cai, G.P. Zhou, C.H. Jen, S.L. Lin, K.C. Chou, Identify catalytic triads of serine hydrolases by support vector machines, J. Theor. Biol., 228 (2004) 551-557.

106. K.C. Chou, Insights from modelling the $3 \mathrm{D}$ structure of the extracellular domain of a7 nicotinic acetylcholine receptor, Biochem. Biophys. Res. Commun., 319 (2004) 433-438.

107. K.C. Chou, Modelling extracellular domains of GABA-A receptors: subtypes 1, 2, 3, and 5, Biochemical and Bi- 
ophysical Research Communications (BBRC), 316 (2004) 636-642.

108. K.C. Chou, Insights from modelling three-dimensional structures of the human potassium and sodium channels, Journal of Proteome Research, 3 (2004) 856-861.

109. K.C. Chou, Insights from modelling the tertiary structure of BACE2, Journal of Proteome Research, 3 (2004) 1069-1072.

110. K.C. Chou, Review: Structural bioinformatics and its impact to biomedical science, Current Medicinal Chemistry, 11 (2004) 2105-2134.

111. K.C. Chou, Insights from modelling the 3D structure of the extracellular domain of alpha7 nicotinic acetylcholine receptor, Biochemical and Biophysical Research Communication (BBRC), 319 (2004) 433-438.

112. K.C. Chou, Molecular therapeutic target for type-2 diabetes, Journal of Proteome Research, 3 (2004) 1284-1288.

113. K.C. Chou, Preface, Current Medicinal Chemistry, 11 (2004) 2103.

114. K.C. Chou, Y.D. Cai, A novel approach to predict active sites of enzyme molecules, Proteins: Struct., Funct., Genet., 55 (2004) 77-82.

115. K.C. Chou, Y.D. Cai, Predicting enzyme family class in a hybridization space, Protein Science, 13 (2004) 2857-2863.

116. K.C. Chou, Y.D. Cai, Prediction of protein subcellular locations by GO-FunD-PseAA predicor, Biochemical and Biophysical Research Communications (BBRC), 320 (2004) 1236-1239.

117. K.C. Chou, Y.D. Cai, Using GO-PseAA predictor to predict enzyme sub-class, Biochemical and Biophysical Research Communications (BBRC), 325 (2004) 506-509.

118. K.C. Chou, Y.D. Cai, Predicting subcellular localization of proteins by hybridizing functional domain composition and pseudo amino acid composition, J. Cell. Biochem., 91 (2004) 1197-1203.

119. Q.S. Du, S.Q. Wang, D.Q. Wei, Y. Zhu, H. Guo, S. Sirois, K.C. Chou, Polyprotein Cleavage Mechanism of SARS CoV Mpro and Chemical Modification of Octapeptide, Peptides, 25 (2004) 1857-1864.

120. J.G. Geng, M. Chen, K.C. Chou, P-selectin Cell Adhesion Molecule in Inflammation, Thrombosis, Cancer Growth and Metastasis., Current Medicinal Chemistry, 11 (2004) 2153-2160.

121. S. Sirois, D.Q. Wei, Q.S. Du, K.C. Chou, Virtual Screening for SARS-CoV Protease Based on KZ7088 Pharmacophore Points, J. Chem. Inf. Comput. Sci., 44 (2004) 1111-1122.

122. M. Wang, J. Yang, G.P. Liu, Z.J. Xu, K.C. Chou, Weighted-support vector machines for predicting membrane protein types based on pseudo amino acid composition, Protein Engineering, Design, and Selection, 17 (2004) 509-516.

123. Y.D. Cai, K.C. Chou, Using functional domain composition to predict enzyme family classes, Journal of Proteome Research, 4 (2005) 109-111.

124. Y.D. Cai, K.C. Chou, Predicting enzyme subclass by functional domain composition and pseudo amino acid composition, Journal of Proteome Research, 4 (2005) 967-971.

125. Y.D. Cai, G.P. Zhou, K.C. Chou, Predicting enzyme family classes by hybridizing gene product composition and pseudo amino acid composition, J. Theor. Biol., 234 (2005) 145-149.

126. K.C. Chou, Using amphiphilic pseudo amino acid composition to predict enzyme subfamily classes, Bioinformatics, 21 (2005) 10-19.

127. K.C. Chou, Insights from modeling the 3D structure of DNA-CBF3b complex, Journal of Proteome Research, 4 (2005) 1657-1660.

128. K.C. Chou, Coupling interaction between thromboxane A2 receptor and alpha-13 subunit of guanine nucleo- 
tide-binding protein, Journal of Proteome Research, 4 (2005) 1681-1686.

129. K.C. Chou, Review: Progress in protein structural class prediction and its impact to bioinformatics and proteomics, Current Protein and Peptide Science, 6 (2005) 423-436.

130. K.C. Chou, Y.D. Cai, Predicting protein localization in budding yeast, Bioinformatics, 21 (2005) 944-950.

131. K.C. Chou, Y.D. Cai, Prediction of membrane protein types by incorporating amphipathic effects, Journal of Chemical Information and Modeling, 45 (2005) 407-413.

132. K.C. Chou, Y.D. Cai, Using GO-PseAA predictor to identify membrane proteins and their types, Biochem Biophys Res Comm (BBRC), 327 (2005) 845-847.

133. Q.S. Du, P.G. Mezey, K.C. Chou, Heuristic Molecular Lipophilicity Potential (HMLP): A 2D-QSAR Study to LADH of Molecular Family Pyrazole and Derivatives, J. Comput. Chem., 26 (2005) 461-470.

134. Q.S. Du, S. Wang, D.Q. Wei, S. Sirois, K.C. Chou, Molecular modelling and chemical modification for finding peptide inhibitor against SARS CoV Mpro, Anal. Biochem., 337 (2005) 262-270.

135. Q.S. Du, S.Q. Wang, Z.Q. Jiang, W.N. Gao, Y.D. Li, D.Q. Wei, K.C. Chou, Application of bioinformatics in search for cleavable peptides of SARS-CoV Mpro and chemical modification of octapeptides, Medicinal Chemistry, 1 (2005) 209-213.

136. K.Y. Feng, Y.D. Cai, K.C. Chou, Boosting classifier for predicting protein domain structural class, Biochemical \& Biophysical Research Communications (BBRC), 334 (2005) 213-217.

137. Y. Gao, S.H. Shao, X. Xiao, Y.S. Ding, Y.S. Huang, Z.D. Huang, K.C. Chou, Using pseudo amino acid composition to predict protein subcellular location: approached with Lyapunov index, Bessel function, and Chebyshev filter, Amino Acids, 28 (2005) 373-376.

138. H. Liu, J. Yang, J.G. Ling, K.C. Chou, Prediction of protein signal sequences and their cleavage sites by statistical rulers, Biochem Biophys Res Comm (BBRC), 338 (2005) 1005-1011.

139. H. Liu, J. Yang, M. Wang, L. Xue, K.C. Chou, Using Fourier spectrum analysis and pseudo amino acid composition for prediction of membrane protein types, The Protein Journal, 24 (2005) 385-389.

140. H.B. Shen, K.C. Chou, Predicting protein subnuclear location with optimized evidence-theoretic K-nearest classifier and pseudo amino acid composition, Biochem Biophys Res Comm. (BBRC), 337 (2005) 752-756.

141. H.B. Shen, J. Yang, X.J. Liu, K.C. Chou, Using supervised fuzzy clustering to predict protein structural classes, Biochem Biophys Res Commun (BBRC), 334 (2005) 577-581.

142. T.L. Shi, Y.X. Li, Y.D. Cai, K.C. Chou, Review: Computational methods for protein - protein interaction and their application, Current Protein and Peptide Science, 6 (2005) 443-449.

143. S. Sirois, G.E. Hatzakis, D.Q. Wei, Q.S. Du, K.C. Chou, Assessment of chemical libraries for their druggability, Computational Biology \& Chemistry, 29 (2005) 55-67.

144. S. Sirois, T. Sing, K.C. Chou, Review: HIV-1 gp120 V3 loop for structure-based drug design, Current Protein and Peptide Science, 6 (2005) 413-422.

145. S. Sirois, C.M. Tsoukas, K.C. Chou, D.Q. Wei, C. Boucher, G.E. Hatzakis, Selection of Molecular Descriptors with Artificial Intelligence for the Understanding of HIV-1 Protease Peptidomimetic Inhibitors-activity, Medicinal Chemistry, 1 (2005) 173-184.

146. M. Wang, J. Yang, K.C. Chou, Using string kernel to predict signal peptide cleavage site based on subsite coupling model, Amino Acids (Erratum, ibid. 2005, 29: 301), 28 (2005) 395-402.

147. M. Wang, J. Yang, Z.J. Xu, K.C. Chou, SLLE for predicting membrane protein types, J. Theor. Biol., 232 (2005) 7-15.

148. M. Wang, J.S. Yao, Z.D. Huang, Z.J. Xu, G.P. Liu, H.Y. Zhao, X.Y. Wang, J. Yang, Y.S. Zhu, K.C. Chou, A new 
nucleotide-composition based fingerprint of SARS-CoV with visualization analysis, Medicinal Chemistry, 1 (2005) 39-47.

149. D.Q. Wei, K.C. Chou, Y.R. Gan, Q.S. Du, A Polypeptide and Its Derivatives as Inhibitors Against SARS, Patent Application No: CN 1560074A, January 2005China, 2005.

150. D.Q. Wei, S. Sirois, Q.S. Du, H.R. Arias, K.C. Chou, Theoretical studies of Alzheimer's disease drug candidate [(2,4-dimethoxy) benzylidene]-anabaseine dihydrochloride (GTS-21) and its derivatives, Biochem Biophys Res Commun (BBRC), 338 (2005) 1059-1064.

151. X. Xiao, S. Shao, Y. Ding, Z. Huang, X. Chen, K.C. Chou, Using cellular automata to generate Image representation for biological sequences, Amino Acids, 28 (2005) 29-35.

152. X. Xiao, S. Shao, Y. Ding, Z. Huang, X. Chen, K.C. Chou, An Application of Gene Comparative Image for Predicting the Effect on Replication Ratio by HBV Virus Gene Missense Mutation, J. Theor. Biol., 235 (2005) 555-565.

153. X. Xiao, S. Shao, Y. Ding, Z. Huang, Y. Huang, K.C. Chou, Using complexity measure factor to predict protein subcellular location, Amino Acids, 28 (2005) 57-61.

154. Z.R. Yang, L. Wang, N. Young, K.C. Chou, Review: Pattern recognition methods for protein functional site prediction, Current Protein and Peptide Science, 6 (2005) 479-491.

155. Y. Bai, D. Wang, Z.X. Yu, Y. Jia, F.Y. Zhu, D.Q. Wei, W.Z. Zhong, K.C. Chou, Ecdysterone determination of niuxi by the near-infrared diffuse reflection spectroscopy (NIRDRS), Spectroscopy, 21 (2006) 40-43.

156. Y.D. Cai, K.C. Chou, Predicting membrane protein type by functional domain composition and pseudo amino acid composition, J. Theor. Biol., 238 (2006) 395-400.

157. K.C. Chou, Y.D. Cai, Prediction of protease types in a hybridization space, Biochem Biophys Res Comm (BBRC), 339 (2006) 1015-1020.

158. K.C. Chou, Y.D. Cai, Predicting protein-protein interactions from sequences in a hybridization space, Journal of Proteome Research, 5 (2006) 316-322.

159. K.C. Chou, Y.D. Cai, W.Z. Zhong, Predicting networking couples for metabolic pathways of Arabidopsis, EXCLI Journal (Experimental and Clinical Sciences International Online Journal for Advances in Science), 5 (2006) 55-65 (openly accessible at http://www.excli.de/vol55/Chou07-06proofrev.pdf).

160. K.C. Chou, H.B. Shen, Predicting protein subcellular location by fusing multiple classifiers, J. Cell. Biochem., 99 (2006) 517-527.

161. K.C. Chou, H.B. Shen, Hum-PLoc: A novel ensemble classifier for predicting human protein subcellular localization, Biochem. Biophys. Res. Commun. (BBRC), 347 (2006) 150-157.

162. K.C. Chou, H.B. Shen, Predicting eukaryotic protein subcellular location by fusing optimized evidence-theoretic K-nearest neighbor classifiers, Journal of Proteome Research, 5 (2006) 1888-1897.

163. K.C. Chou, H.B. Shen, Addendum to "Hum-PLoc: A novel ensemble classifier for predicting human protein subcellular localization”, Biochem. Biophys. Res. Commun. (BBRC), 348 (2006) 1479.

164. K.C. Chou, D.Q. Wei, Q.S. Du, S. Sirois, W.Z. Zhong, Review: Progress in computational approach to drug development against SARS, Current Medicinal Chemistry, 13 (2006) 3263-3270.

165. Q.S. Du, Z.Q. Jiang, W.Z. He, D.P. Li, K.C. Chou, Amino acid principal component analysis (AAPCA) and its applications in protein structural class prediction, Journal of Biomolecular Structure and Dynamics (JBSD), 23 (2006) 635-640.

166. Q.S. Du, D.P. Li, W.Z. He, K.C. Chou, Heuristic molecular lipophilicity potential (HMLP): lipophilicity and hydrophilicity of amino acid side chains, J. Comput. Chem., 27 (2006) 685-692. 
167. L. Gao, Y.S. Ding, H. Dai, S.H. Shao, Z.D. Huang, K.C. Chou, A novel fingerprint map for detecting SARS-CoV, Journal of Pharmaceutical and Biomedical Analysis, 41 (2006) 246-250.

168. W. Kem, F. Soti, S. LeFrancois, K. Wildeboer, K. MacDougall, D.Q. Wei, K.C. Chou, H.R. Arias, Review: The nemertine toxin anabaseine and its derivative DMXBA (GTS-21): chemical and pharmacological properties, Marine Drugs, 4 (2006) 255-273.

169. H.B. Shen, J. Yang, K.C. Chou, Fuzzy KNN for predicting membrane protein types from pseudo amino acid composition, J. Theor. Biol., 240 (2006) 9-13.

170. S.Q. Wang, J. Yang, K.C. Chou, Using stacked generalization to predict membrane protein types based on pseudo amino acid composition, J. Theor. Biol., 242 (2006) 941-946.

171. D.Q. Wei, Q.S. Du, H. Sun, K.C. Chou, Insights from modeling the 3D structure of H5N1 influenza virus neuraminidase and its binding interactions with ligands, Biochem Biophys Res Comm (BBRC), 344 (2006) 1048-1055.

172. X. Xiao, S.H. Shao, K.C. Chou, A probability cellular automaton model for hepatitis B viral infections, Biochem Biophys Res Comm (BBRC), 342 (2006) 605-610.

173. X. Xiao, S.H. Shao, Y.S. Ding, Z.D. Huang, K.C. Chou, Using cellular automata images and pseudo amino acid composition to predict protein subcellular location, Amino Acids, 30 (2006) 49-54.

174. R. Zhang, D.Q. Wei, Q.S. Du, K.C. Chou, Molecular modeling studies of peptide drug candidates against SARS, Medicinal Chemistry, 2 (2006) 309-314.

175. J. Chen, H. Liu, J. Yang, K.C. Chou, Prediction of linear B-cell epitopes using amino acid pair antigenicity scale, Amino Acids, 33 (2007) 423-428.

176. K.C. Chou, H.B. Shen, Euk-mPLoc: a fusion classifier for large-scale eukaryotic protein subcellular location prediction by incorporating multiple sites, Journal of Proteome Research, 6 (2007) 1728-1734.

177. K.C. Chou, H.B. Shen, Signal-CF: a subsite-coupled and window-fusing approach for predicting signal peptides, Biochem Biophys Res Comm (BBRC), 357 (2007) 633-640.

178. K.C. Chou, H.B. Shen, MemType-2L: A Web server for predicting membrane proteins and their types by incorporating evolution information through Pse-PSSM, Biochem Biophys Res Comm (BBRC), 360 (2007) 339-345.

179. K.C. Chou, H.B. Shen, Recent progresses in protein subcellular location prediction, Anal. Biochem., 370 (2007) $1-16$.

180. Y.S. Ding, T.L. Zhang, K.C. Chou, Prediction of protein structure classes with pseudo amino acid composition and fuzzy support vector machine network, Protein \& Peptide Letters, 14 (2007) 811-815.

181. Q.S. Du, R.B. Huang, Y.T. Wei, C.H. Wang, K.C. Chou, Peptide reagent design based on physical and chemical properties of amino acid residues, J. Comput. Chem., 28 (2007) 2043-2050.

182. Q.S. Du, H. Sun, K.C. Chou, Inhibitor design for SARS coronavirus main protease based on "distorted key theory", Medicinal Chemistry, 3 (2007) 1-6.

183. Q.S. Du, S.Q. Wang, K.C. Chou, Analogue inhibitors by modifying oseltamivir based on the crystal neuraminidase structure for treating drug-resistant H5N1 virus, Biochem Biophys Res Comm (BBRC), 362 (2007) 525-531.

184. Q.S. Du, Y.T. Wei, Z.W. Pang, K.C. Chou, R.B. Huang, Predicting the affinity of epitope-peptides with class I MHC molecule HLA-A*0201: an application of amino acid-based peptide prediction, Protein Engineering, Design \& Selection, 20 (2007) 417-423.

185. W.N. Gao, D.Q. Wei, Y. Li, H. Gao, W.R. Xu, A.X. Li, K.C. Chou, Agaritine and its derivatives are potential inhibitors against HIV proteases, Medicinal Chemistry, 3 (2007) 221-226.

186. L. Li, D.Q. Wei, J.F. Wang, K.C. Chou, Computational studies of the binding mechanism of calmodulin with 
chrysin, Biochem Biophys Res Comm (BBRC), 358 (2007) 1102-1107.

187. D.Q. Liu, H. Liu, H.B. Shen, J. Yang, K.C. Chou, Predicting secretory protein signal sequence cleavage sites by fusing the marks of global alignments, Amino Acids, 32 (2007) 493-496.

188. H.B. Shen, K.C. Chou, Using ensemble classifier to identify membrane protein types, Amino Acids, 32 (2007) 483-488.

189. H.B. Shen, K.C. Chou, Gpos-PLoc: an ensemble classifier for predicting subcellular localization of Gram-positive bacterial proteins, Protein Engineering, Design, and Selection, 20 (2007) 39-46.

190. H.B. Shen, K.C. Chou, EzyPred: A top-down approach for predicting enzyme functional classes and subclasses, Biochem Biophys Res Comm (BBRC), 364 (2007) 53-59.

191. H.B. Shen, K.C. Chou, Nuc-PLoc: A new web-server for predicting protein subnuclear localization by fusing PseAA composition and PsePSSM, Protein Engineering, Design \& Selection, 20 (2007) 561-567.

192. H.B. Shen, J. Yang, K.C. Chou, Review: Methodology development for predicting subcellular localization and other attributes of proteins, Expert Review of Proteomics, 4 (2007) 453-463.

193. S. Sirois, M. Touaibia, K.C. Chou, R. Roy, Review: Glycosylation of HIV-1 gp120 V3 loop: towards the rational design of a synthetic carbohydrate vaccine, Current Medicinal Chemistry, 14 (2007) 3232-3242.

194. S.Q. Wang, Q.S. Du, K. Zhao, A.X. Li, D.Q. Wei, K.C. Chou, Virtual screening for finding natural inhibitor against cathepsin-L for SARS therapy, Amino Acids, 33 (2007) 129-135.

195. H. Wei, R. Zhang, C. Wang, H. Zheng, K.C. Chou, D.Q. Wei, Molecular insights of SAH enzyme catalysis and their implication for inhibitor design, J. Theor. Biol., 244 (2007) 692-702.

196. X. Xiao, K.C. Chou, Digital coding of amino acids based on hydrophobic index, Protein \& Peptide Letters, 14 (2007) 871-875.

197. G. Aguero-Chapin, A. Antunes, F.M. Ubeira, K.C. Chou, H. Gonzalez-Diaz, Comparative Study of Topological Indices of Macro/Supra-molecular RNA Complex Networks, Journal of Chemical Information \& Modeling, 48 (2008) 2265-2277.

198. K.C. Chou, H.B. Shen, Cell-PLoc: A package of Web servers for predicting subcellular localization of proteins in various organisms, Nature Protocols, 3 (2008) 153-162.

199. K.C. Chou, H.B. Shen, ProtIdent: A web server for identifying proteases and their types by fusing functional domain and sequential evolution information, Biochem. Biophys. Res. Comm. (BBRC), 376 (2008) 321-325.

200. M. Cruz-Monteagudo, C.R. Munteanu, F. Borges, M. Natália, D.S. Cordeiro, E. Uriarte, K.C. Chou, H. Gonzalez-Diaz, Stochastic molecular descriptors for polymers. 4. Study of complex mixtures with topological indices of mass spectra spiral and star networks: the blood proteome case, Polymer, 49 (2008) 5575-5587.

201. Q.S. Du, R.B. Huang, K.C. Chou, Review: Recent advances in QSAR and their applications in predicting the activities of chemical molecules, peptides and proteins for drug design, Current Protein \& Peptide Science, 9 (2008) 248-259.

202. Q.S. Du, R.B. Huang, Y.T. Wei, L.Q. Du, K.C. Chou, Multiple Field Three Dimensional Quantitative Structure-Activity Relationship (MF-3D-QSAR), J. Comput. Chem., 29 (2008) 211-219.

203. X.L. Guo, L. Li, D.Q. Wei, Y.S. Zhu, K.C. Chou, Cleavage mechanism of the H5N1 hemagglutinin by trypsin and furin, Amino Acids, 35 (2008) 375-382.

204. R.B. Huang, Q.S. Du, C.H. Wang, K.C. Chou, An in-depth analysis of the biological functional studies based on the NMR M2 channel structure of influenza A virus, Biochem. Biophys Res Comm. (BBRC), 377 (2008) 1243-1247.

205. H.B. Shen, K.C. Chou, PseAAC: a flexible web-server for generating various kinds of protein pseudo amino acid 
composition, Anal. Biochem., 373 (2008) 386-388.

206. H.B. Shen, K.C. Chou, HIVcleave: a web-server for predicting HIV protease cleavage sites in proteins, Anal. Biochem., 375 (2008) 388-390.

207. J.F. Wang, D.Q. Wei, C. Chen, Y. Li, K.C. Chou, Molecular modeling of two CYP2C19 SNPs and its implications for personalized drug design, Protein \& Peptide Letters, 15 (2008) 27-32.

208. J.F. Wang, D.Q. Wei, H.L. Du, Y.X. Li, K.C. Chou, Molecular modeling studies on NADP-dependence of Candida tropicalis strain xylose reductase, The Open Bioinformatics Journal, 2 (2008) 72-79.

209. J.F. Wang, D.Q. Wei, L. Li, K.C. Chou, Review: Pharmacogenomics and personalized use of drugs, Current Topics of Medicinal Chemistry, 8 (2008) 1573-1579.

210. J.F. Wang, D.Q. Wei, L. Li, K.C. Chou, Review: Drug candidates from traditional Chinese medicines, Current Topics in Medicinal Chemistry, 8 (2008) 1656-1665.

211. T. Wang, J. Yang, H.B. Shen, K.C. Chou, Predicting membrane protein types by the LLDA algorithm, Protein \& Peptide Letters, 15 (2008) 915-921.

212. X. Xiao, P. Wang, K.C. Chou, Predicting protein structural classes with pseudo amino acid composition: an approach using geometric moments of cellular automaton image, J. Theor. Biol., 254 (2008) 691-696.

213. Z.R. Yang, K.C. Chou, Correlation of metabolic pathways with the primary structure in acetylated proteins, The Open Bioinformatics Journal, 2 (2008) 90-96.

214. S.W. Zhang, Y.L. Zhang, Q. Pan, Y.M. Cheng, K.C. Chou, Estimating residue evolutionary conservation by introducing von Neumann entropy and a novel gap-treating approach, Amino Acids, 35 (2008) 495-501.

215. T.L. Zhang, Y.S. Ding, K.C. Chou, Prediction protein structural classes with pseudo amino acid composition: approximate entropy and hydrophobicity pattern, J. Theor. Biol., 250 (2008) 186-193.

216. K.C. Chou, Automated prediction of protein attributes and its impact to biomedicine and drug discovery, in: G. Alterovitz, Benson, R., and Ramoni, M. F. (Ed.) Automation in Proteomics and Genomics: An Engineering Case-Based Approach (Harvard-MIT interdisciplinary special studies courses), Chap.5, pp. 97-143, Wiley \& Sons, Ltd., West Sussex, UK, 2009, pp. 97-143.

217. K.C. Chou, Pseudo amino acid composition and its applications in bioinformatics, proteomics and system biology, Current Proteomics, 6 (2009) 262-274.

218. K.C. Chou, H.B. Shen, Recent advances in developing web-servers for predicting protein attributes Natural Science, 1 (2009) 63-92

219. K.C. Chou, D.Q. Wei, Q.S. Du, S. Sirois, H.B. Shen, W.Z. Zhong, Study of inhibitors against SARS coronavirus by computational approaches, in: U. Lendeckel, N.M. Hooper (Eds.) Proteases in Biology and Disease: Viral proteases and antiviral protease inhibitor therapy, Springer Science, Media B.V., 2009, pp. 1-23.

220. Y.S. Ding, T.L. Zhang, Q. Gu, P.Y. Zhao, K.C. Chou, Using maximum entropy model to predict protein secondary structure with single sequence, Protein \& Peptide Letters, 16 (2009) 552-560.

221. Q.S. Du, R.B. Huang, C.H. Wang, X.M. Li, K.C. Chou, Energetic analysis of the two controversial drug binding sites of the M2 proton channel in influenza A virus, J. Theor. Biol., 259 (2009) 159-164.

222. Q.S. Du, R.B. Huang, Y.T. Wei, Z.W. Pang, L.Q. Du, K.C. Chou, Fragment-Based Quantitative Structure-Activity Relationship (FB-QSAR) for Fragment-Based Drug Design, J. Comput. Chem., 30 (2009) 295-304.

223. K. Gong, L. Li, J.F. Wang, F. Cheng, D.Q. Wei, K.C. Chou, Binding mechanism of H5N1 influenza virus neuraminidase with ligands and its implication for drug design, Medicinal Chemistry, 5 (2009) 242-249.

224. R.X. Gu, H. Gu, Z.Y. Xie, J.F. Wang, H.R. Arias, D.Q. Wei, K.C. Chou, Possible drug candidates for Alzheimer's disease deduced from studying their binding interactions with alpha7 nicotinic acetylcholine receptor, Medicin- 
al Chemistry, 5 (2009) 250-262.

225. R.B. Huang, Q.S. Du, Y.T. Wei, Z.W. Pang, H. Wei, K.C. Chou, Physics and chemistry-driven artificial neural network for predicting bioactivity of peptides and proteins and their design, J. Theor. Biol., 256 (2009) $428-435$.

226. A. Madkan, M. Blank, E. Elson, K.C. Chou, M.S. Geddis, R. Goodman, Steps to the clinic with ELF EMF Natural Science 1(2009) 157-165.

227. H.B. Shen, K.C. Chou, Predicting protein fold pattern with functional domain and sequential evolution information, J. Theor. Biol., 256 (2009) 441-446.

228. H.B. Shen, K.C. Chou, Identification of proteases and their types, Anal. Biochem., 385 (2009) 153-160.

229. H.B. Shen, K.C. Chou, A top-down approach to enhance the power of predicting human protein subcellular localization: Hum-mPLoc 2.0, Anal. Biochem., 394 (2009) 269-274.

230. H.B. Shen, K.C. Chou, Gpos-mPLoc: A top-down approach to improve the quality of predicting subcellular localization of Gram-positive bacterial proteins, Protein \& Peptide Letters, 16 (2009) 1478-1484.

231. H.B. Shen, J.F. Wang, L.X. Yao, J. Yang, K.C. Chou, Recent progress of bioinformatics in membrane protein structural studies, in: G. Alterovitz, Benson, R., and Ramoni, M. F. (Ed.) Automation in Proteomics and Genomics: An Engineering Case-Based Approach (Harvard-MIT interdisciplinary special studies courses), Chap.12, pp.293-308, John Wiley \& Sons, Ltd., West Sussex, UK, 2009.

232. J.F. Wang, J.Y. Yan, D.Q. Wei, K.C. Chou, Binding of CYP2C9 with diverse drugs and its implications for metabolic mechanism, Medicinal Chemistry, 5 (2009) 263-270.

233. J.F. Wang, C.C. Zhang, K.C. Chou, D.Q. Wei, Review: Structure of cytochrome P450s and personalized drug, Current Medicinal Chemistry, 16 (2009) 232-244.

234. J.F. Wang, C.C. Zhang, J.Y. Yan, K.C. Chou, D.Q. Wei, Molecular modeling of CYP proteins and its implication for personal drug design, in: G. Alterovitz, Benson, R., and Ramoni, M. F. (Ed.) Automation in Proteomics and Genomics: An Engineering Case-Based Approach (Harvard-MIT interdisciplinary special studies courses), Chap.11, pp.275-292, John Wiley \& Sons, Ltd., West Sussex, UK, 2009.

235. H. Wei, C.H. Wang, Q.S. Du, J. Meng, K.C. Chou, Investigation into adamantane-based M2 inhibitors with FB-QSAR, Medicinal Chemistry, 5 (2009) 305-317.

236. X. Xiao, P. Wang, K.C. Chou, Predicting protein quaternary structural attribute by hybridizing functional domain composition and pseudo amino acid composition, J. Appl. Crystallogr., 42 (2009) 169-173.

237. L. Chen, T. Huang, X.H. Shi, Y.D. Cai, K.C. Chou, Analysis of protein pathway networks using hybrid properties, Molecules, 15 (2010) 8177-8192 (Openly accessible at http://www.mdpi.com/journal/molecules).

238. K.C. Chou, Graphic rule for drug metabolism systems, Current Drug Metabolism, 11 (2010) 369-378.

239. K.C. Chou, The Cradle of Gordon Life Science Institute and its Development and Driving Force (Short Communication), Biomedical Journal of Scientific \& Technology Research, 23 (2010) 17848-17863.

240. K.C. Chou, H.B. Shen, Cell-PLoc 2.0: An improved package of web-servers for predicting subcellular localization of proteins in various organisms, Natural Science, 2 (2010) 1090-1103.

241. Q.S. Du, R.B. Huang, K.C. Chou, Advances in visual representation of molecular potentials, Expert Opinion on Drug Discovery, 5 (2010) 513-527.

242. Q.S. Du, R.B. Huang, S.Q. Wang, K.C. Chou, Designing inhibitors of M2 proton channel against H1N1 swine influenza virus, PLoS ONE, 5 (2010) e9388.

243. Q.S. Du, S.Q. Wang, R.B. Huang, K.C. Chou, Computational 3D structures of drug-targeting proteins in the 2009-H1N1 influenza A virus, Chem. Phys. Lett., 485 (2010) 191-195.

244. J.P. Qi, Y.S. Ding, S.H. Shao, X.H. Zeng, K.C. Chou, Cellular responding kinetics based on a model of gene reg- 
ulatory networks under radiotherapy, Health 2: 137-146 (2010).

245. H.B. Shen, K.C. Chou, Gneg-mPLoc: A top-down strategy to enhance the quality of predicting subcellular localization of Gram-negative bacterial proteins, Journal of Theoretical Biology, 264 (2010) 326-333.

246. L. Cai, Y. Wang, J.F. Wang, K.C. Chou, Identification of proteins interacting with human SP110 during the process of viral infections, Medicinal Chemistry, 7 (2011) 121-126.

247. K.C. Chou, Some remarks on protein attribute prediction and pseudo amino acid composition (50th Anniversary Year Review, 5-steps rule), J. Theor. Biol., 273 (2011) 236-247.

248. K.C. Chou, W.Z. Lin, X. Xiao, Wenxiang: a web-server for drawing wenxiang diagrams Natural Science, 3 (2011) 862-865.

249. Q.S. Du, H. Wei, R.B. Huang, K.C. Chou, Progress in structure-based drug design against influenza A virus, Expert Opinion, 6 (2011) 619-631.

250. L. Hu, T. Huang, X. Shi, W.C. Lu, Y.D. Cai, K.C. Chou, Predicting functions of proteins in mouse based on weighted protein-protein interaction network and protein hybrid properties PLoS ONE, 6 (2011) e14556.

251. L.L. Hu, C. Chen, T. Huang, Y.D. Cai, K.C. Chou, Predicting biological functions of compounds based on chemical-chemical interactions, PLoS ONE, 6 (2011) e29491.

252. L.L. Hu, S. Niu, X.H. Shi, Y.D. Cai, K.C. Chou, Prediction and analysis of protein palmitoylation sites Biochimie, 93 (2011) 489-496.

253. T. Huang, L. Chen, Y.D. Cai, K.C. Chou, Classification and analysis of regulatory pathways using graph property, biochemical and physicochemical property, and functional property, PLoS ONE, 6 (2011) e25297.

254. W.Z. Lin, J.A. Fang, X. Xiao, K.C. Chou, iDNA-Prot: Identification of DNA Binding Proteins Using Random Forest with Grey Model, PLoS ONE, 6 (2011) e24756.

255. L.H. Ren, Y.Z. Shen, Y.S. Ding, K.C. Chou, Bio-entity network for analysis of protein-protein interaction networks, Asian Journal of Control, 13 (2011) 726-737.

256. S.B. Wan, L.L. Hu, S. Niu, K. Wang, Y.D. Cai, K.C. Chou, Identification of multiple subcellular locations for proteins in budding yeast, Current Bioinformatics, 6 (2011) 71-80.

257. J.F. Wang, K.C. Chou, Insights from modeling the 3D structure of New Delhi metallo-beta-lactamase and its binding interactions with antibiotic drugs, PLoS ONE 6(2011) e18414.

258. Z.Z. Wen, Y.H. Wang, B. Yang, M.Q. Xie, K.C. Chou, Roles of L5-7 Loop in the Structure and Chaperone Function of SsHSP14.1, Protein Pept Lett, 18 (2011) 275-281.

259. X. Xiao, K.C. Chou, Using pseudo amino acid composition to predict protein attributes via cellular automata and other approaches, Current Bioinformatics, 6 (2011) 251-260.

260. X. Xiao, P. Wang, K.C. Chou, Cellular automata and its applications in protein bioinformatics, Current Protein \& Peptide Science, 12 (2011) 508-519.

261. X. Xiao, P. Wang, K.C. Chou, GPCR-2L: Predicting G protein-coupled receptors and their types by hybridizing two different modes of pseudo amino acid compositions, Molecular Biosystems, 7 (2011) 911-919.

262. X. Xiao, P. Wang, K.C. Chou, Quat-2L: a web-server for predicting protein quaternary structural attributes, Molecular Diversity, 15 (2011) 149-155.

263. W. Chen, H. Lin, P.M. Feng, C. Ding, Y.C. Zuo, K.C. Chou, iNuc-PhysChem: A Sequence-Based Predictor for Identifying Nucleosomes via Physicochemical Properties, PLoS ONE, 7 (2012) e47843.

264. K.C. Chou, Z.C. Wu, X. Xiao, iLoc-Hum: Using accumulation-label scale to predict subcellular locations of human proteins with both single and multiple sites, Molecular Biosystems, 8 (2012) 629-641.

265. Y. Ma, S.Q. Wang, W.R. Xu, R.L. Wang, K.C. Chou, Design novel dual agonists for treating type-2 diabetes by 
targeting peroxisome proliferator-activated receptors with core hopping approach, PLoS One, 7 (2012) e38546.

266. J.F. Wang, K.C. Chou, Insights into the Mutation-Induced HHH Syndrome from Modeling Human Mitochondrial Ornithine Transporter-1, PLoS One, 7 (2012) e31048.

267. X. Xiao, W.Z. Lin, K.C. Chou, Recent advances in predicting G-protein coupled receptor classification, Current Bioinformatics, 7 (2012) 132-142.

268. X. Xiao, P. Wang, K.C. Chou, iNR-PhysChem: A Sequence-Based Predictor for Identifying Nuclear Receptors and Their Subfamilies via Physical-Chemical Property Matrix, PLoS ONE, 7 (2012) e30869.

269. W. Chen, P.M. Feng, H. Lin, K.C. Chou, iRSpot-PseDNC: identify recombination spots with pseudo dinucleotide composition Nucleic Acids Research 41 (2013) e68.

270. K.C. Chou, Some remarks on predicting multi-label attributes in molecular biosystems, Molecular Biosystems, 9 (2013) 1092-1100.

271. K.C. Chou, Predicting Drugs Side Effects Based on Chemical-Chemical Interactions and Protein-Chemical Interactions, BioMed Research International, 2013 (2013) 8.

272. P.M. Feng, W. Chen, H. Lin, K.C. Chou, iHSP-PseRAAAC: Identifying the heat shock protein families using pseudo reduced amino acid alphabet composition, Anal. Biochem., 442 (2013) 118-125.

273. Y. Ji, Y.X. Li, Y.D. Cai, K.C. Chou, Metagenome assembly validation: which metagenome contigs are bona fide?, Current Bioinformatics, 8 (2013) 511-523.

274. W.Z. Lin, J.A. Fang, X. Xiao, K.C. Chou, iLoc-Animal: A multi-label learning classifier for predicting subcellular localization of animal proteins Molecular BioSystems, 9 (2013) 634-644.

275. L. Liu, Y. Ma, R.L. Wang, W.R. Xu, S.Q. Wang, K.C. Chou, Find novel dual-agonist drugs for treating type 2 diabetes by means of cheminformatics, Drug Design, Development and Therapy 7(2013) 279-287.

276. J.L. Min, X. Xiao, K.C. Chou, iEzy-Drug: A web server for identifying the interaction between enzymes and drugs in cellular networking, BioMed Research International (BMRI), 2013 (2013) 701317.

277. J.F. Wang, K.C. Chou, Metallo-beta-Lactamases: Structural Features, Antibiotic Recognition, Inhibition, and Inhibitor Design, Current Topics in Medicinal Chemistry, 13 (2013) 1242-1253.

278. X. Xiao, W.Z. Lin, K.C. Chou, Recent advances in predicting protein classification and their applications to drug development, Current Topics in Medicinal Chemistry, 13 (2013) 1622-1635.

279. X. Xiao, J.L. Min, P. Wang, K.C. Chou, iGPCR-Drug: A web server for predicting interaction between GPCRs and drugs in cellular networking, PLoS ONE, 8 (2013) e72234.

280. X. Xiao, J.L. Min, P. Wang, K.C. Chou, Predict drug-protein interaction in cellular networking, Current Topics in Medicinal Chemistry, 13 (2013) 1707-1712.

281. X. Xiao, P. Wang, K.C. Chou, Recent progresses in identifying nuclear receptors and their families, Current Topics in Medicinal Chemistry, 13 (2013) 1192-1200.

282. X. Xiao, P. Wang, W.Z. Lin, J.H. Jia, K.C. Chou, iAMP-2L: A two-level multi-label classifier for identifying antimicrobial peptides and their functional types, Anal. Biochem., 436 (2013) 168-177.

283. Y. Xu, J. Ding, L.Y. Wu, K.C. Chou, iSNO-PseAAC: Predict cysteine S-nitrosylation sites in proteins by incorporating position specific amino acid propensity into pseudo amino acid composition PLoS ONE, 8 (2013) e55844.

284. Y. Xu, X.J. Shao, L.Y. Wu, N.Y. Deng, K.C. Chou, iSNO-AAPair: incorporating amino acid pairwise coupling into PseAAC for predicting cysteine S-nitrosylation sites in proteins, PeerJ, 1 (2013) e171.

285. W. Chen, P.M. Feng, E.Z. Deng, H. Lin, K.C. Chou, iTIS-PseTNC: a sequence-based predictor for identifying translation initiation site in human genes using pseudo trinucleotide composition, Anal. Biochem., 462 (2014) 
76-83.

286. W. Chen, P.M. Feng, H. Lin, K.C. Chou, iSS-PseDNC: identifying splicing sites using pseudo dinucleotide composition, Biomed Research International (BMRI), 2014 (2014) 623149.

287. W. Chen, T.Y. Lei, D.C. Jin, H. Lin, K.C. Chou, PseKNC: a flexible web-server for generating pseudo K-tuple nucleotide composition, Anal. Biochem., 456 (2014) 53-60.

288. H. Ding, E.Z. Deng, L.F. Yuan, L. Liu, H. Lin, W. Chen, K.C. Chou, iCTX-Type: A sequence-based predictor for identifying the types of conotoxins in targeting ion channels, BioMed Research International (BMRI), 2014 (2014) 286419.

289. Y.N. Fan, X. Xiao, J.L. Min, K.C. Chou, iNR-Drug: Predicting the interaction of drugs with nuclear receptors in cellular networking, Intenational Journal of Molecular Sciences (IJMS), 15 (2014) 4915-4937.

290. S.H. Guo, E.Z. Deng, L.Q. Xu, H. Ding, H. Lin, W. Chen, K.C. Chou, iNuc-PseKNC: a sequence-based predictor for predicting nucleosome positioning in genomes with pseudo k-tuple nucleotide composition, Bioinformatics, 30 (2014) 1522-1529.

291. H. Lin, E.Z. Deng, H. Ding, W. Chen, K.C. Chou, iPro54-PseKNC: a sequence-based predictor for identifying sigma-54 promoters in prokaryote with pseudo k-tuple nucleotide composition, Nucleic Acids Res., 42 (2014) 12961-12972.

292. B. Liu, J. Xu, X. Lan, R. Xu, J. Zhou, X. Wang, K.C. Chou, iDNA-Prot|dis: identifying DNA-binding proteins by incorporating amino acid distance-pairs and reduced alphabet profile into the general pseudo amino acid composition, PLoS ONE, 9 (2014) e106691.

293. B. Liu, D. Zhang, R. Xu, J. Xu, X. Wang, Q. Chen, Q. Dong, K.C. Chou, Combining evolutionary information extracted from frequency profiles with sequence-based kernels for protein remote homology detection, Bioinformatics, 30 (2014) 472-479.

294. W.R. Qiu, X. Xiao, K.C. Chou, iRSpot-TNCPseAAC: Identify recombination spots with trinucleotide composition and pseudo amino acid components, Int J Mol Sci (IJMS), 15 (2014) 1746-1766.

295. Y. Xu, X. Wen, X.J. Shao, N.Y. Deng, K.C. Chou, iHyd-PseAAC: Predicting hydroxyproline and hydroxylysine in proteins by incorporating dipeptide position-specific propensity into pseudo amino acid composition, Int. J. Mol. Sci., 15 (2014) 7594-7610.

296. Y. Xu, X. Wen, L.S. Wen, L.Y. Wu, N.Y. Deng, K.C. Chou, iNitro-Tyr: Prediction of nitrotyrosine sites in proteins with general pseudo amino acid composition, PLoS ONE, 9 (2014) e105018.

297. L. Cai, C.L. Wan, L. He, S. Jong, K.C. Chou, Gestational influenza increases the risk of psychosis in adults, Medicinal Chemistry, 11 (2015) 676-682.

298. W. Chen, P. Feng, H. Ding, H. Lin, K.C. Chou, iRNA-Methyl: Identifying N6-methyladenosine sites using pseudo nucleotide composition, Anal. Biochem., 490 (2015) 26-33.

299. W. Chen, P. Feng, H. Ding, H. Lin, K.C. Chou, Benchmark data for identifying N6-methyladenosine sites in the Saccharomyces cerevisiae genome, Data in brief, 5 (2015) 376-378.

300. W. Chen, H. Lin, K.C. Chou, Pseudo nucleotide composition or PseKNC: an effective formulation for analyzing genomic sequences, Mol BioSyst, 11 (2015) 2620-2634.

301. W. Chen, X. Zhang, J. Brooker, H. Lin, L. Zhang, K.C. Chou, PseKNC-General: a cross-platform package for generating various modes of pseudo nucleotide compositions, Bioinformatics, 31 (2015) 119-120.

302. K.C. Chou, Impacts of bioinformatics to medicinal chemistry, Medicinal Chemistry, 11 (2015) 218 -234.

303. K.C. Chou, An unprecedented revolution in medicinal science, Proceedings of the MOL2NET (International Conference on Multidisciplinary Sciences) 1(2015) 1-10. 
304. J. Jia, Z. Liu, X. Xiao, K.C. Chou, iPPI-Esml: an ensemble classifier for identifying the interactions of proteins by incorporating their physicochemical properties and wavelet transforms into PseAAC, J. Theor. Biol., 377 (2015) 47-56.

305. B. Liu, L. Fang, F. Liu, X. Wang, J. Chen, K.C. Chou, Identification of real microRNA precursors with a pseudo structure status composition approach, PLoS ONE, 10 (2015) e0121501.

306. B. Liu, L. Fang, S. Wang, X. Wang, H. Li, K.C. Chou, Identification of microRNA precursor with the degenerate K-tuple or Kmer strategy, Journal of Theoretical Biology, 385 (2015) 153-159.

307. B. Liu, F. Liu, L. Fang, X. Wang, K.C. Chou, repDNA: a Python package to generate various modes of feature vectors for DNA sequences by incorporating user-defined physicochemical properties and sequence-order effects, Bioinformatics, 31 (2015) 1307-1309.

308. B. Liu, F. Liu, X. Wang, J. Chen, L. Fang, K.C. Chou, Pse-in-One: a web server for generating various modes of pseudo components of DNA, RNA, and protein sequences, Nucleic Acids Res., 43 (2015) W65-W71.

309. J. Liu, J. Song, M.Y. Wang, L. He, L. Cai, K.C. Chou, Association of EGF rs4444903 and XPD rs13181 polymorphisms with cutaneous melanoma in Caucasians, Medicinal Chemistry, 11 (2015) 551-559.

310. Z. Liu, X. Xiao, W.R. Qiu, K.C. Chou, iDNA-Methyl: Identifying DNA methylation sites via pseudo trinucleotide composition, Anal. Biochem., 474 (2015) 69-77.

311. W.R. Qiu, X. Xiao, W.Z. Lin, K.C. Chou, iUbiq-Lys: Prediction of lysine ubiquitination sites in proteins by extracting sequence evolution information via a grey system model Journal of Biomolecular Structure and Dynamics (JBSD) 33 (2015) 1731-1742.

312. X. Xiao, J.L. Min, W.Z. Lin, Z. Liu, X. Cheng, K.C. Chou, iDrug-Target: predicting the interactions between drug compounds and target proteins in cellular networking via the benchmark dataset optimization approach, $J$ Biomol Struct Dyn (JBSD), 33 (2015) 2221-2233.

313. R. Xu, J. Zhou, B. Liu, Y.A. He, Q. Zou, X. Wang, K.C. Chou, Identification of DNA-binding proteins by incorporating evolutionary information into pseudo amino acid composition via the top-n-gram approach, Journal of Biomolecular Structure \& Dynamics (JBSD), 33 (2015) 1720-1730.

314. L. Cai, Y.H. Yang, L. He, K.C. Chou, Modulation of cytokine network in the comorbidity of schizophrenia and tuberculosis, Curr Top Med Chem, 16 (2016) 655-665.

315. L. Cai, W. Yuan, Z. Zhang, L. He, K.C. Chou, In-depth comparison of somatic point mutation callers based on different tumor next-generation sequencing depth data Scientific Reports, 6 (2016) 36540.

316. J. Chen, R. Long, X.L. Wang, B. Liu, K.C. Chou, dRHP-PseRA: detecting remote homology proteins using profile-based pseudo protein sequence and rank aggregation, Scientific Reports, (2016) 6:32333.

317. W. Chen, H. Ding, P. Feng, H. Lin, K.C. Chou, iACP: a sequence-based tool for identifying anticancer peptides, Oncotarget, 7 (2016) 16895-16909.

318. W. Chen, P. Feng, H. Ding, H. Lin, K.C. Chou, Using deformation energy to analyze nucleosome positioning in genomes, Genomics, 107 (2016) 69-75.

319. W. Chen, H. Tang, J. Ye, H. Lin, K.C. Chou, iRNA-PseU: Identifying RNA pseudouridine sites Molecular Therapy - Nucleic Acids 5 (2016) e332.

320. J. Jia, Z. Liu, X. Xiao, B. Liu, K.C. Chou, Identification of protein-protein binding sites by incorporating the physicochemical properties and stationary wavelet transforms into pseudo amino acid composition (iPPBS-PseAAC), J Biomol Struct Dyn (JBSD) 34 (2016) 1946-1961.

321. J. Jia, Z. Liu, X. Xiao, B. Liu, K.C. Chou, iSuc-PseOpt: Identifying lysine succinylation sites in proteins by incorporating sequence-coupling effects into pseudo components and optimizing imbalanced training dataset, 
Anal. Biochem., 497 (2016) 48-56.

322. J. Jia, Z. Liu, X. Xiao, B. Liu, K.C. Chou, pSuc-Lys: Predict lysine succinylation sites in proteins with PseAAC and ensemble random forest approach, J. Theor. Biol., 394 (2016) 223-230.

323. J. Jia, Z. Liu, X. Xiao, B. Liu, K.C. Chou, iCar-PseCp: identify carbonylation sites in proteins by Monto Carlo sampling and incorporating sequence coupled effects into general PseAAC, Oncotarget, 7 (2016) 34558-34570.

324. J. Jia, Z. Liu, X. Xiao, B. Liu, K.C. Chou, iPPBS-Opt: A Sequence-Based Ensemble Classifier for Identifying Protein-Protein Binding Sites by Optimizing Imbalanced Training Datasets, Molecules, 21 (2016) E95.

325. J. Jia, L. Zhang, Z. Liu, X. Xiao, K.C. Chou, pSumo-CD: Predicting sumoylation sites in proteins with covariance discriminant algorithm by incorporating sequence-coupled effects into general PseAAC, Bioinformatics, 32 (2016) 3133-3141.

326. B. Liu, L. Fang, R. Long, X. Lan, K.C. Chou, iEnhancer-2L: a two-layer predictor for identifying enhancers and their strength by pseudo k-tuple nucleotide composition, Bioinformatics, 32 (2016) 362-369.

327. B. Liu, F. Liu, L. Fang, X. Wang, K.C. Chou, repRNA: a web server for generating various feature vectors of RNA sequences, Molecular Genetics and Genomics, 291 (2016) 473-481.

328. B. Liu, R. Long, K.C. Chou, iDHS-EL: Identifying DNase I hypersensi-tivesites by fusing three different modes of pseudo nucleotide composition into an ensemble learning framework, Bioinformatics, 32 (2016) 2411-2418.

329. Z. Liu, X. Xiao, D.J. Yu, J. Jia, W.R. Qiu, K.C. Chou, pRNAm-PC: Predicting N-methyladenosine sites in RNA sequences via physical-chemical properties, Anal. Biochem., 497 (2016) 60-67.

330. W.R. Qiu, B.Q. Sun, X. Xiao, Z.C. Xu, K.C. Chou, iHyd-PseCp: Identify hydroxyproline and hydroxylysine in proteins by incorporating sequence-coupled effects into general PseAAC, Oncotarget, 7 (2016) 44310-44321.

331. W.R. Qiu, B.Q. Sun, X. Xiao, Z.C. Xu, K.C. Chou, iPTM-mLys: identifying multiple lysine PTM sites and their different types, Bioinformatics, 32 (2016) 3116-3123.

332. W.R. Qiu, X. Xiao, Z.C. Xu, K.C. Chou, iPhos-PseEn: identifying phosphorylation sites in proteins by fusing different pseudo components into an ensemble classifier, Oncotarget, 7 (2016) 51270-51283.

333. A. Vaseghi, M. Faridounnia, S. Shokrollahzade, S. Jahandideh, K.C. Chou, Prediction of protein quaternary structures in Pattern Recognition, in "Computational Molecular Biology: Techniques and Approaches, Chap. 14” (Ed. Elloumi, M; Iliopoulos, CS; Wang, JTL; Zomaya, AY), John Wiley \& Sons, New Jersey, 2016.

334. X. Xiao, H.X. Ye, Z. Liu, J.H. Jia, K.C. Chou, iROS-gPseKNC: predicting replication origin sites in DNA by incorporating dinucleotide position-specific propensity into general pseudo nucleotide composition, Oncotarget, 7 (2016) 34180-34189.

335. Y. Xu, K.C. Chou, Recent progress in predicting posttranslational modification sites in proteins, Curr Top Med Chem, 16 (2016) 591-603.

336. C.J. Zhang, H. Tang, W.C. Li, H. Lin, W. Chen, K.C. Chou, iOri-Human: identify human origin of replication by incorporating dinucleotide physicochemical properties into pseudo nucleotide composition, Oncotarget, 7 (2016) 69783-69793.

337. Y. Zhu, Q.W. Cong, Y. Liu, C.L. Wan, T. Yu, G. He, L. He, L. Cai, K.C. Chou, Antithrombin is an importantly inhibitory role against blood clots, Curr Top Med Chem, 16 (2016) 666-674.

338. W. Chen, P. Feng, H. Yang, H. Ding, H. Lin, K.C. Chou, iRNA-AI: identifying the adenosine to inosine editing sites in RNA sequences, Oncotarget, 8 (2017) 4208-4217.

339. X. Cheng, X. Xiao, K.C. Chou, pLoc-mPlant: predict subcellular localization of multi-location plant proteins via incorporating the optimal GO information into general PseAAC, Molecular BioSystems, 13 (2017) 1722-1727.

340. X. Cheng, X. Xiao, K.C. Chou, pLoc-mVirus: predict subcellular localization of multi-location virus proteins via 
incorporating the optimal GO information into general PseAAC, Gene (Erratum: ibid., 2018, Vol.644, 156-156), 628 (2017) 315-321.

341. X. Cheng, S.G. Zhao, W.Z. Lin, X. Xiao, K.C. Chou, pLoc-mAnimal: predict subcellular localization of animal proteins with both single and multiple sites, Bioinformatics, 33 (2017) 3524-3531.

342. X. Cheng, S.G. Zhao, X. Xiao, K.C. Chou, iATC-mISF: a multi-label classifier for predicting the classes of anatomical therapeutic chemicals, Bioinformatics (Corrigendum, ibid., 2017, Vol.33, 2610), 33 (2017) 341-346.

343. X. Cheng, S.G. Zhao, X. Xiao, K.C. Chou, iATC-mHyb: a hybrid multi-label classifier for predicting the classification of anatomical therapeutic chemicals, Oncotarget, 8 (2017) 58494-58503.

344. K.C. Chou, An unprecedented revolution in medicinal chemistry driven by the progress of biological science, Current Topics in Medicinal Chemistry, 17 (2017) 2337-2358.

345. Q.S. Du, S.Q. Wang, N.Z. Xie, Q.Y. Wang, R.B. Huang, K.C. Chou, 2L-PCA: A two-level principal component analyzer for quantitative drug design and its applications, Oncotarget, 8 (2017) 70564-70578.

346. P. Feng, H. Ding, H. Yang, W. Chen, H. Lin, K.C. Chou, iRNA-PseColl: Identifying the occurrence sites of different RNA modifications by incorporating collective effects of nucleotides into PseKNC, Molecular Therapy Nucleic Acids 7(2017) 155-163.

347. B. Liu, S. Wang, R. Long, K.C. Chou, iRSpot-EL: identify recombination spots with an ensemble learning approach, Bioinformatics, 33 (2017) 35-41.

348. B. Liu, H. Wu, K.C. Chou, Pse-in-One 2.0: An improved package of web servers for generating various modes of pseudo components of DNA, RNA, and protein sequences, Natural Science, 9 (2017) 67-91.

349. B. Liu, H. Wu, D. Zhang, X. Wang, K.C. Chou, Pse-Analysis: a python package for DNA/RNA and protein/peptide sequence analysis based on pseudo components and kernel methods, Oncotarget, 8 (2017) 13338-13343.

350. B. Liu, F. Yang, K.C. Chou, 2L-piRNA: A two-layer ensemble classifier for identifying piwi-interacting RNAs and their function, Molecular Therapy - Nucleic Acids, 7 (2017) 267-277.

351. L.M. Liu, Y. Xu, K.C. Chou, iPGK-PseAAC: identify lysine phosphoglycerylation sites in proteins by incorporating four different tiers of amino acid pairwise coupling information into the general PseAAC, Med Chem, 13 (2017) 552-559.

352. B. Niu, M. Zhang, P. Du, L. Jiang, R. Qin, Q. Su, F. Chen, D. Du, Y. Shu, K.C. Chou, Small molecular floribundiquinone B derived from medicinal plants inhibits acetylcholinesterase activity, Oncotarget, 8 (2017) 57149-57162.

353. W.R. Qiu, S.Y. Jiang, B.Q. Sun, X. Xiao, X. Cheng, K.C. Chou, iRNA-2methyl: identify RNA 2'-O-methylation sites by incorporating sequence-coupled effects into general PseKNC and ensemble classifier, Medicinal Chemistry, 13 (2017) 734-743.

354. W.R. Qiu, S.Y. Jiang, Z.C. Xu, X. Xiao, K.C. Chou, iRNAm5C-PseDNC: identifying RNA 5-methylcytosine sites by incorporating physical-chemical properties into pseudo dinucleotide composition, Oncotarget, 8 (2017) 41178-41188.

355. W.R. Qiu, B.Q. Sun, X. Xiao, D. Xu, K.C. Chou, iPhos-PseEvo: Identifying human phosphorylated proteins by incorporating evolutionary information into general PseAAC via grey system theory, Molecular Informatics, 36 (2017) UNSP 1600010.

356. Q. Su, W. Lu, D. Du, F. Chen, B. Niu, K.C. Chou, Prediction of the aquatic toxicity of aromatic compounds to tetrahymena pyriformis through support vector regression, Oncotarget, 8 (2017) 49359-49369.

357. J. Wang, B. Yang, J. Revote, A. Leier, T.T. Marquez-Lago, G. Webb, J. Song, K.C. Chou, T. Lithgow, POSSUM: a bioinformatics toolkit for generating numerical sequence feature descriptors based on PSSM profiles, Bioinformatics, 33 (2017) 2756-2758. 
358. X. Xiao, X. Cheng, S. Su, Q. Nao, K.C. Chou, pLoc-mGpos: Incorporate key gene ontology information into general PseAAC for predicting subcellular localization of Gram-positive bacterial proteins, Natural Science, 9 (2017) 330-349.

359. Y. Xu, C. Li, K.C. Chou, iPreny-PseAAC: identify C-terminal cysteine prenylation sites in proteins by incorporating two tiers of sequence couplings into PseAAC, Med Chem, 13 (2017) 544-551.

360. Z.D. Zhang, K. Liang, K. Li, G.Q. Wang, K.W. Zhang, L. Cai, S.T. Zha, K.C. Chou, Chlorella vulgaris induces apoptosis of human non-small cell lung carcinoma (NSCLC) cells, Med Chem, 13 (2017) 560-568.

361. L. Cai, T. Huang, J. Su, X. Zhang, W. Chen, F. Zhang, L. He, K.C. Chou, Implications of newly identified brain eQTL genes and their interactors in Schizophrenia, Molecular Therapy - Nucleic Acids, 12 (2018) 433-442.

362. W. Chen, H. Ding, X. Zhou, H. Lin, K.C. Chou, iRNA(m6A)-PseDNC: Identifying N6-methyladenosine sites using pseudo dinucleotide composition, Anal. Biochem., 561-562 (2018) 59-65.

363. W. Chen, P. Feng, H. Yang, H. Ding, H. Lin, K.C. Chou, iRNA-3typeA: identifying 3-types of modification at RNA's adenosine sites, Molecular Therapy: Nucleic Acid, 11 (2018) 468-474.

364. Z. Chen, X. Liu, F. Li, C. Li, T. Marquez-Lago, A. Leier, T. Akutsu, G.I. Webb, D. Xu, A.I. Smith, L. Li, K.C. Chou, J. Song, Large-scale comparative assessment of computational predictors for lysine post-translational modification sites, Brief in Bioinform (2018).

365. Z. Chen, P.Y. Zhao, F. Li, Leier A, T.T. Marquez-Lago, Y. Wang, G.I. Webb, A.I. Smith, R.J. Daly, K.C. Chou, J. Song, iFeature: a python package and web server for features extraction and selection from protein and peptide sequences, Bioinformatics, 34 (2018) 2499-2502.

366. X. Cheng, X. Xiao, K.C. Chou, pLoc-mEuk: Predict subcellular localization of multi-label eukaryotic proteins by extracting the key GO information into general PseAAC, Genomics, 110 (2018) 50-58.

367. X. Cheng, X. Xiao, K.C. Chou, pLoc-mGneg: Predict subcellular localization of Gram-negative bacterial proteins by deep gene ontology learning via general PseAAC, Genomics, 110 (2018) 231-239.

368. X. Cheng, X. Xiao, K.C. Chou, pLoc-mHum: predict subcellular localization of multi-location human proteins via general PseAAC to winnow out the crucial GO information, Bioinformatics, 34 (2018) 1448-1456.

369. X. Cheng, X. Xiao, K.C. Chou, pLoc_bal-mGneg: predict subcellular localization of Gram-negative bacterial proteins by quasi-balancing training dataset and general PseAAC, Journal of Theoretical Biology, 458 (2018) 92-102.

370. X. Cheng, X. Xiao, K.C. Chou, pLoc_bal-mPlant: predict subcellular localization of plant proteins by general PseAAC and balancing training dataset Curr Pharm Des, 24 (2018) 4013-4022.

371. A. Ehsan, K. Mahmood, Y.D. Khan, S.A. Khan, K.C. Chou, A Novel Modeling in Mathematical Biology for Classification of Signal Peptides, Scientific Reports, 8 (2018) 1039.

372. Y.D. Khan, N. Rasool, W. Hussain, S.A. Khan, K.C. Chou, iPhosT-PseAAC: Identify phosphothreonine sites by incorporating sequence statistical moments into PseAAC, Anal. Biochem., 550 (2018) 109-116.

373. Y.D. Khan, N. Rasool, W. Hussain, S.A. Khan, K.C. Chou, iPhosY-PseAAC: identify phosphotyrosine sites by incorporating sequence statistical moments into PseAAC, Molecular biology reports, 45 (2018) 2501-2509.

374. F. Li, C. Li, T.T. Marquez-Lago, A. Leier, T. Akutsu, A.W. Purcell, A.I. Smith, T. Lightow, R.J. Daly, J. Song, K.C. Chou, Quokka: a comprehensive tool for rapid and accurate prediction of kinase family-specific phosphorylation sites in the human proteome, Bioinformatics, 34 (2018) 4223-4231.

375. F. Li, Y. Wang, C. Li, T.T. Marquez-Lago, A. Leier, N.D. Rawlings, G. Haffari, J. Revote, T. Akutsu, K.C. Chou, A.W. Purcell, R.N. Pike, G.I. Webb, A. Ian Smith, T. Lithgow, R.J. Daly, J.C. Whisstock, J. Song, Twenty years of bioinformatics research for protease-specific substrate and cleavage site prediction: a comprehensive revisit and benchmarking of existing methods, Brief in Bioinform (2018). 
376. B. Liu, K. Li, D.S. Huang, K.C. Chou, iEnhancer-EL: Identifying enhancers and their strength with ensemble learning approach, Bioinformatics, 34 (2018) 3835-3842.

377. B. Liu, F. Weng, D.S. Huang, K.C. Chou, iRO-3wPseKNC: Identify DNA replication origins by three-window-based PseKNC, Bioinformatics, 34 (2018) 3086-3093.

378. B. Liu, F. Yang, D.S. Huang, K.C. Chou, iPromoter-2L: a two-layer predictor for identifying promoters and their types by multi-window-based PseKNC, Bioinformatics, 34 (2018) 33-40.

379. W.R. Qiu, B.Q. Sun, X. Xiao, Z.C. Xu, J.H. Jia, K.C. Chou, iKcr-PseEns: Identify lysine crotonylation sites in histone proteins with pseudo components and ensemble classifier, Genomics, 110 (2018) 239-246.

380. J. Song, F. Li, A. Leier, T.T. Marquez-Lago, T. Akutsu, G. Haffari, K.C. Chou, G.I. Webb, R.N. Pike, PROSPERous: high-throughput prediction of substrate cleavage sites for 90 proteases with improved accuracy, Bioinformatics, 34 (2018) 684-687.

381. J. Song, F. Li, K. Takemoto, G. Haffari, T. Akutsu, K.C. Chou, G.I. Webb, PREvaIL, an integrative approach for inferring catalytic residues using sequence, structural and network features in a machine learning framework, Journal of Theoretical Biology, 443 (2018) 125-137.

382. J. Song, Y. Wang, F. Li, T. Akutsu, N.D. Rawlings, G.I. Webb, K.C. Chou, iProt-Sub: a comprehensive package for accurately mapping and predicting protease-specific substrates and cleavage sites, Brief in Bioinform, 20 (2018) 638-658.

383. Z.D. Su, Y. Huang, Z.Y. Zhang, Y.W. Zhao, D. Wang, W. Chen, K.C. Chou, H. Lin, iLoc-lncRNA: predict the subcellular location of IncRNAs by incorporating octamer composition into general PseKNC, Bioinformatics, 34 (2018) 4196-4204.

384. J. Wang, J. Li, B. Yang, R. Xie, T.T. Marquez-Lago, A. Leier, M. Hayashida, T. Akutsu, Y. Zhang, K.C. Chou, J. Selkrig, T. Zhou, J. Song, T. Lithgow, Bastion3: a two-layer approach for identifying type III secreted effectors using ensemble learning, Bioinformatics, 35 (2018) 2017-2028.

385. J. Wang, B. Yang, A. Leier, T.T. Marquez-Lago, M. Hayashida, A. Rocker, Z. Yanju, T. Akutsu, K.C. Chou, R.A. Strugnell, J. Song, T. Lithgow, Bastion6: a bioinformatics approach for accurate prediction of type VI secreted effectors, Bioinformatics, 34 (2018) 2546-2555.

386. H. Yang, W.R. Qiu, G. Liu, F.B. Guo, W. Chen, K.C. Chou, H. Lin, iRSpot-Pse6NC: Identifying recombination spots in Saccharomyces cerevisiae by incorporating hexamer composition into general PseKNC International Journal of Biological Sciences, 14 (2018) 883-891.

387. Y. Zhang, R. Xie, J. Wang, A. Leier, T.T. Marquez-Lago, T. Akutsu, G.I. Webb, K.C. Chou, J. Song, Computational analysis and prediction of lysine malonylation sites by exploiting informative features in an integrative machine-learning framework, Brief in Bioinform (2018).

388. O. Barukab, Y.D. Khan, S.A. Khan, K.C. Chou, iSulfoTyr-PseAAC: Identify tyrosine sulfation sites by incorporating statistical moments via Chou's 5-steps rule and pseudo components Current Genomics, 20 (2019) 306-320.

389. X. Cheng, W.Z. Lin, X. Xiao, K.C. Chou, pLoc_bal-mAnimal: predict subcellular localization of animal proteins by balancing training dataset and PseAAC, Bioinformatics, 35 (2019) 398-406.

390. K.C. Chou, Advance in predicting subcellular localization of multi-label proteins and its implication for developing multi-target drugs, Current Medicinal Chemistry 26 (2019) 4918-4943.

391. K.C. Chou, Recent progresses in predicting protein subcellular localization with artificial intelligence tools developed via the 5-steps rule, Medicinal Chemistry, Submitted (2019).

392. K.C. Chou, Impacts of pseudo amino acid components and 5-steps rule to proteomics and proteome analysis, Current Topics in Medicinak Chemistry (CTMC) (Special Issue ed. G.P Zhou), 19 (2019) 2283-2300. 
393. K.C. Chou, Proposing pseudo amino acid components is an important milestone for proteome and genome analyses (2019), International Journal for Peptide Research and Therapeutics (IJPRT) 26 (2019) 1085-1098.

394. K.C. Chou, Two kinds of metrics for computational biology, Genomics, (2019).

395. K.C. Chou, An insightful recollection for predicting protein subcellular locations in multi-label systems, Natural Science, (2019).

396. K.C. Chou, Artificial intelligence (AI) tools constructed via the 5-steps rule for predicting post-translational modifications, Trends in Artificial Inttelengence (TIA), 3 (2019) 60-74.

397. K.C. Chou, Recent Progresses in Predicting Protein Subcellular Localization with Artificial Intelligence (AI) Tools Developed Via the 5-Steps Rule, Japanese Journal of Gastroenterology and Hepatology 2(2019) 1-4. https://www.jigastrohepto.org/v2issue4.php

398. K.C. Chou, An insightful recollection since the distorted key theory was born about 23 years ago, Genomics (2019). https://doi.org/10.1016/j.ygeno.2019.09.001 https://www.sciencedirect.com/science/article/pii/S0888754319305543?via\%3Dihub

399. K.C. Chou, An insightful recollection since the birth of Gordon Life Science Institute about 17 years ago, Advancement in Scientific and Engineering Research 4(2019) 31-36.

400. K.C. Chou, Gordon Life Science Institute: Its philosophy, achievements, and perspective, Annals of Cancer Therapy and Pharmacology 2(2019) 001-026.

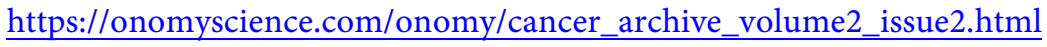

401. K.C. Chou, An Insightful 10-year Recollection Since the Emergence of the 5-steps Rule, Current Pharmaceutical Design, 25 (2019) 4223-4234.

402. K.C. Chou, An Insightful 20-Year Recollection Since the Birth of Pseudo Amino Acid Components, JOURNAL OF MATHEMATICS, STATISTICS AND COMPUTING, 1 (2019) 5-16.

403. K.C. Chou, Intriguing Story about the Birth of Gordon Life Science Institute and its Development and Driving Force, J Retro Virol Anti Retro Virol 1(2019) 180002.

404. K.C. Chou, Showcase to illustrate how the web-server iNitro-Tyr is working, Glo J of Com Sci and Infor Tec., 2 (2019) 1-16.

405. K.C. Chou, Showcase to illustrate how the web-server iDNA6mA-PseKNC is working, Journal of Pathology Research Reviews \& Reports, 1 (2019) 1-15.

406. K.C. Chou, The pLoc_bal-mPlant is a Powerful Artificial Intelligence Tool for Predicting the Subcellular Localization of Plant Proteins Purely based on their Sequence Information, Int J Nutr Sci., 4 (2019) 1-4.

407. K.C. Chou, Intriguing Story about the Birth of Gordon Life Science Institute and its Development and Driving Force, J Retro Virol Anti Retro Virol, 1 (2019) 180002.

408. K.C. Chou, The pLoc_bal-mPlant is a powerful artificial intelligence tool for predicting the subcellular localization of plant proteins purely based on their sequence information, J Stem Cell Res Med, 4 (2019) 1-4.

409. K.C. Chou, Showcase to Illustrate How the Web-Server pLoc_bal-mEuk is Working, JSM Clin Cytol Pathol, 4 (2019) 1-2.

410. K.C. Chou, Showcase to illustrate how the web-server iDNA6mA-PseKNC is working, Journal of Pathology Research Reviews \& Reports, 1 (2019) 1-15.

411. K.C. Chou, The cradle of Gordon Life Science Institute and its development and driving force (Review Article), Int J Biol Genetics, 1 (2019) 1-28.

412. K.C. Chou, How the artificial intelligence tool iSNO-PseAAC is working in predicting the cysteine S-nitrosylation sites in proteins, J Stem Cell Res Med, 4 (2019) 1-9. 
413. K.C. Chou, The pLoc_bal-mAnimal is a powerful artificial intelligence tool for predicting the subcellular localization of animal proteins based on their sequence information alone, Scientific Journal of Biometrics \& Biostatistics, 2 (2019) 1-13.

414. K.C. Chou, X. Cheng, X. Xiao, pLoc_bal-mHum: predict subcellular localization of human proteins by PseAAC and quasi-balancing training dataset Genomics, 111 (2019) 1274-1282.

415. K.C. Chou, X. Cheng, X. Xiao, pLoc_bal-mEuk: predict subcellular localization of eukaryotic proteins by general PseAAC and quasi-balancing training dataset, Med Chem, 15 (2019) 472-485.

416. A. Ehsan, M.K. Mahmood, Y.D. Khan, O.M. Barukab, S.A. Khan, K.C. Chou, iHyd-PseAAC (EPSV): Identify hydroxylation sites in proteins by extracting enhanced position and sequence variant feature via Chou's 5-step rule and general pseudo amino acid composition, Current Genomics, 20 (2019) 124-133.

417. P. Feng, H. Yang, H. Ding, H. Lin, W. Chen, K.C. Chou, iDNA6mA-PseKNC: Identifying DNA N(6)-methyladenosine sites by incorporating nucleotide physicochemical properties into PseKNC, Genomics, 111 (2019) 96-102.

418. W. Hussain, S.D. Khan, N. Rasool, S.A. Khan, K.C. Chou, SPalmitoylC-PseAAC: A sequence-based model developed via Chou's 5-steps rule and general PseAAC for identifying S-palmitoylation sites in proteins, Anal. Biochem., 568 (2019) 14-23.

419. W. Hussain, Y.D. Khan, N. Rasool, S.A. Khan, K.C. Chou, SPrenylC-PseAAC: A sequence-based model developed via Chou's 5-steps rule and general PseAAC for identifying S-prenylation sites in proteins, J. Theor. Biol., 468 (2019) 1-11.

420. S. Ilyas, W. Hussain, A. Ashraf, Y.D. Khan, S.A. Khan, K.C. Chou, iMethylK-PseAAC: Improving accuracy for lysine methylation sites identification by incorporating statistical moments and position relative features into general PseAAC via Chou's 5-steps rule, Current Genomics (2019).

421. J. Jia, X. Li, W. Qiu, X. Xiao, K.C. Chou, iPPI-PseAAC(CGR): Identify protein-protein interactions by incorporating chaos game representation into PseAAC, Journal of Theoretical Biology, 460 (2019) 195-203.

422. S. Khan, M. Khan, N. Iqbal, T. Hussain, S.A. Khan, K.C. Chou, A Two-Level Computation Model Based on Deep Learning Algorithm for Identification of piRNA and Their Functions via Chou's 5-Steps Rule Human Genetics 19 (2019) 756-799.

423. Y.D. Khan, A. Batool, N. Rasool, A. Khan, K.C. Chou, Prediction of nitrosocysteine sites using position and composition variant features, Letters in Organic Chemistry, 16 (2019) 283-293.

424. Y.D. Khan, M. Jamil, W. Hussain, N. Rasool, S.A. Khan, K.C. Chou, pSSbond-PseAAC: Prediction of disulfide bonding sites by integration of PseAAC and statistical moments, J. Theor. Biol., 463 (2019) 47-55.

425. F. Li, Y. Zhang, A.W. Purcell, G.I. Webb, K.C. Chou, T. Lithgow, C. Li, J. Song, Positive-unlabelled learning of glycosylation sites in the human proteome, BMC Bioinformatics, 20 (2019) 112.

426. Y. Lu, S. Wang, J. Wang, G. Zhou, Q. Zhang, X. Zhou, B. Niu, Q. Chen, K.C. Chou, An Epidemic Avian Influenza Prediction Model Based on Google Trends, Letters in Organic Chemistry, 16 (2019) 303-310.

427. X. Xiao, X. Cheng, G. Chen, Q. Mao, K.C. Chou, pLoc_bal-mGpos: predict subcellular localization of Gram-positive bacterial proteins by quasi-balancing training dataset and PseAAC, Genomics, 111 (2019) 886-892.

428. X. Xiao凹 Z.C. Xu囚 W.R. Qiu囚 P. Wang, H.T. Ge, K.C. Chou, iPSW(2L)-PseKNC: A two-layer predictor for identifying promoters and their strength by hybrid features via pseudo K-tuple nucleotide composition, Genomics, 111 (2019) 1785-1793.

429. M. Zhang, F. Li, T.T. Marquez-Lago, A. Leier, C. Fan, C.K. Kwoh, K.C. Chou, J. Song, C. Jia, MULTiPly: a novel multi-layer predictor for discovering general and specific types of promoters, Bioinformatics, 35 (2019) 2957-2965. 
430. K.C. Chou, Progresses in predicting post-translational modification (2019), International Journal of Peptide Research and Therapeutics (IJPRT), 26 (2020) 873-888.

431. K.C. Chou, Distorted Key Theory and Its Implication for Drug Development, Current Genomics, (2020). http://www.eurekaselect.com/175823/article

432. K.C. Chou, Some illuminating remarks on molecular genetics and genomics as well as drug development, Molecular Genetics and Genomics, 295 (2020) 261-274.

433. K.C. Chou, How the Artificial Intelligence Tool iRNA-PseU is Working in Predicting the RNA Pseudouridine Sites, Biomed J Sci \& Tech Res, 24 (2020). https://doi.org/10.26717/BJSTR.2020.24.004016

434. K.C. Chou, Showcase to Illustrate how the webserver pLoc_bal-mEuk Is working, Biomed J Sci \& Tech Res, 24 (2020).

435. K.C. Chou, The pLoc_bal-mGneg Predictor is a Powerful Web-Server for Identifying the Subcellular Localization of Gram-Negative Bacterial Proteins based on their Sequences Information Alone, ijSci, 9 (2020) 27-34.

436. K.C. Chou, How the artificial intelligence tool iRNA-2methyl is working for RNA 2'-Omethylation sites, Journal of Medical Care Research and Review, 3 (2020) 348-366.

437. K.C. Chou, The pLoc_bal-mVirus is a powerful artificial intelligence tool for predicting the subcellular localization of virus proteins according to their sequence information alone, J Gent \& Genome, 4 (2020).

438. K.C. Chou, Showcase to illustrate how the web-server iRNA-Methyl is working, J Mol Genet, 3 (2020) 1-7.

439. K.C. Chou, Showcase to illustrate how the web-server iSNO-AAPair is working, J Gent \& Genome, 4 (2020).

440. K.C. Chou, The pLoc_bal-mHum is a Powerful Web-Serve for Predicting the Subcellular Localization of Human Proteins Purely Based on Their Sequence Information, Adv Bioeng Biomed Sci Res, 3 (2020) 1-5.

441. K.C. Chou, Showcase to Illustrate How the Web-server iPTM-mLys is working, Infotext Journal of Infectious Diseases and Therapy [IJID], 1 (2020) 1-16.

442. K.C. Chou, An insightful 20-year recollection since the birth of pseudo amino acid components, Amino Acids, in press (2020).

443. K.C. Chou, The pLoc_bal-mGpos is a powerful artificial intelligence tool for predicting the subcellular localization of Gram-positive bacterial proteins according to their sequence information alone, Glo J of Com Sci and Infor Tec, 2 (2020) 01-13.

444. K.C. Chou, Showcase to illustrate how the web-server iPreny-PseAAC is working, Glo J of Com Sci and Infor Tec., 2 (2020) 01-15.

445. K.C. Chou, The Most Important Ethical Concerns in Science, Natural Science, 12 (2020) 35-36.

446. K.C. Chou, The Problem of Elsevier Series Journals Online Submission by Using Artificial Intelligence, Natural Science, 12 (2020) 37-38.

447. K.C. Chou, Other Mountain Stones Can Attack Jade: The 5-Steps Rule, Natural Science, 12 (2020) 59-64.

448. K.C. Chou, Using Similarity Software to Evaluate Scientific Paper Quality Is a Big Mistake, Natural Science, 12 (2020) 42-58.

449. K.C. Chou, Proposing 5-Steps Rule Is a Notable Milestone for Studying Molecular Biology, Natural Science, 12 (2020) 74-79.

450. K.C. Chou, How the artificial intelligence tool iHyd-PseAAC is working in predicting the hydroxyproline and hydroxylysine in proteins., MedRead J Hematol, 1 (2020) 1001.

451. K.C. Chou, How the Artificial Intelligence Tool iHyd-PseAAC is Working in Predicting the Hydroxyproline and Hydroxylysine in Proteins, Peer Re J Foren \& Gen Sci, 4 (2020) 272-274. 
452. K.C. Chou, Gordon Life Science Institute and Its Impacts on Computational Biology and Drug Development, Natural Science, 12 (2020) 125-161.

453. K.C. Chou, How the Artificial Intelligence Tool pSumo-CD is Working for Predicting Sumoylation Sites in Proteins, Journal of Biotechnology \& Bioinformatics Research, 1 (2020) 1-3.

454. K.C. Chou, Showcase to illustrate how the web-server pLoc_Deep-mPlant is working, Integrative Molecular Biology and Biotechnology, 1 (2020) 001-002.

455. K.C. Chou, Showcase to illustrate how the web-server pLoc_Deep-mVirus is working, Clinical Research and Trials (Clin Res Trials), 6 (2020) 1-2.

456. K.C. Chou, Showcase to illustrate how the web-server pLoc_Deep-mGneg is working, Clin Med Case Rep J, 1 (2020) 1-2.

457. K.C. Chou, Showcase to illustrate how the web-server pLoc_Deep-mAnimal is working, Am J of Viro and Dis. 2020; 2(1): 01-02., 2 (2020) 01-02.

458. K.C. Chou, How the artificial intelligence tool iHyd-PseAAC is working in predicting the hydroxyproline and hydroxylysine in proteins, ES J Microbiol, 1 (2020) 1004-1006.

459. K.C. Chou, How the artificial intelligence tool iPGK-PseAAC is working in predicting lysine phosphoglycerylation sites in proteins, ES J Microbiol, 1 (2020) 1003-1004.

460. K.C. Chou, The Development of Gordon Life Science Institute: Its Driving Force and Accomplishments, Natural Science, 12 (2020) 202-217.

461. K.C. Chou, Showcase to illustrate how the web-server iATC_Deep-mISF is working, Global Journal of Science Frontier Research: G Bio-Tech \& Genetics 20 (2020) 1-3.

462. K.C. Chou, Showcase to illustrate how the Webserver pLoc_Deep-mGpos is working, Open Acc J Bio Sci, 2 (2020) 345-346.

463. K.C. Chou, Showcase to Illustrate How the Web-Server pLoc_Deep-mEuk Is Working, Advances in Bioscience and Biotecnology (ABB), 11 (2020) 257-272.

464. K.C. Chou, Showcase to Illustrate How the Web-Server pLoc_Deep-mHum Is Working, Advances in Bioscience and Biotechnology (ABB), 11 (2020) 273-288.

465. K.C. Chou, How the artificial intelligence tool iSuc-PseOpt is working for predicting lysine succinylation sites in proteins, Biomedical Research and Clinical Reviews, 1 (2020) 1-2.

466. K.C. Chou, Noah's Ark and Internet Institutes: When and Why? Natural Science, 12 (2020) 470-481.

467. K.C. Chou, The Pandemic Pestilences and Internet Institutes, Natural Science, 12 (2020) 495-515.

468. K.C. Chou, The Implication of "I Am the Alpha and the Omega" to Internet Institutes, Natural Science, 12 (2020) 482-494.

469. K.C. Chou, An Insightful Recollection for Predicting Protein Subcellular Locations in Multi-Label Systems, Natural Science, 12 (2020) 441-469.

470. K.C. Chou, Coronavirus and Gordon Life Science Institute, Natural Science, 12 (2020) 429-440.

471. K.C. Chou, The End of Our Earth Is Certainly to Come: "When"? and "Why"?, Natural Science, 12 (2020) 552-568.

472. K.C. Chou, Showcase to Illustrate How the Web-Server iSulf_Wide-PseAAC Is Working, Natural Science, 12 (2020) 620-631.

473. K.C. Chou, The Significant and Profound Impacts of Chou's 5-Steps Rule, Natural Science, 12 (2020) 633-637.

474. K.C. Chou, The Significant and Profound Impacts of Chou's Distorted Key Theory for Developing Peptide 
Drugs, Natural Science, 12 (2020) 638-639.

475. K.C. Chou, The Significant and Profound Impacts of Chou's Pseudo Amino Acid Composition or PseAAC, Natural Acience, 12 (2020) 647-658.

476. K.C. Chou, A Stimulat Recollection for Chou's Invariance Theorem, Natural Science, 12 (2020) 659-660.

477. K.C. Chou, The Significant and Profound Impacts of Chou's “wenxiang” Diagram, Voice of the Publishers (VP), 6 (2020) 102-103.

478. K.C. Chou, The Significant and Profound Impacts of Pseudo K-Tuple Nucleotide Composition, Voice of the Publisher (VP), 6 (2020) 91-101.

479. K.C. Chou, Revisiting the paper on "Prediction of Tight Turns and Their Types in Proteins" (Short Communication), Scholarly Journal of Food and Nutrition (SJFN), 3 (2020) 374-375.

480. K.C. Chou, The Significant and Profound Impacts of the Studies on the Rate of Diffusion-Controlled Reactions of Enzyme, International Journal of Social Science and Economocs Invention (IJSCEI) 06 (2020) 1-2.

481. K.C. Chou, The Significant and Profound Impacts of the Studies on the Rate of Diffusion-Controlled Reactions of Enzyme (Short Communication), Scholar Journal of Food and Nutrition (SJFN), 3 (2020) 372-373.

482. K.C. Chou, Revisiting the Paper "Origin of the Right-Handed Twist of Beta-Sheets of Poly-L-Valine Chains". (Short Communication), Scholarly Journal of Food and Nutrition (SJFN), 3 (2020) 376-377.

483. K.C. Chou, Analyze the Role of the "5-Steps Rule" Guidelines in Stimulating the Drug Development (Short Communication), Scholarly Journal of Food and Nutrition (SJFN), 3 (2020) 385-386.

484. K.C. Chou, Analyze the Role of "Pseudo Amino Acid Composition" in Stimulating the Drug Development. Annual Cas Rep Rev: ACRR-161, Annals of Case Reports \& Reviews (ACRR), (2020).

485. K.C. Chou, Recent progresses for computationally identifying N6-methyladenosine sites in Saccharomyces cerevisiae, Journal of Applied Mathematics and Computation, 4 (2020) 153-173.

486. K.C. Chou, The significant and profound impacts of protein subcellular localization prediction (Short Communication), Acta Scientific Pharmaceutical Sciences, 4 (2020) 1-3.

487. K.C. Chou, Revisiting the Paper on "Prediction of Human Immunodeficiency Virus Protease Cleavage Sites in Proteins", Archives of Molecular Medicine Journal (Arch Mol Med J), Vol.1 (2020) Page: 1-2.

488. K.C. Chou, The Significant and Profound Impacts of Pseudo K-Tuple Nucleotide Composition, Archives of Molecular Medicine Journal (Arch Mol Med J), Vol.1 (2020) page 1-4.

489. K.C. Chou, The Significant and Profound Impacts of Low-Frequency Internal Motions (Phonons) in Biomacromolecules (Short Communication), Acta Scientific Pharmaceutical Sciences 4(2020) 1-2.

490. K.C. Chou, The Significant and Profound Impacts of Chou's Invariance Theorem (Short Communication), J Med Adv Clin Case Rep, 10 (2020) 1-1.

491. K.C. Chou, Revisiting the Paper on "Prediction of Human Immunodeficiency Virus Protease Cleavage Sites in Proteins" (Short Communication), Archives of Molecular Medicine Journal (Arch Mol Med J), 1 (2020) 1-2.

492. K.C. Chou, A Stimulating Recollection of Chou's "Wenxiang" Diagram (Short Communication), PAST, 1 (2020) 05.

493. K.C. Chou, A Stimulating Recollection of Chou's Graph Theory in Enzyme Kinetics, Voice of Publication (VP), 2020 (2020) 161-163.

494. K.C. Chou, A Stimulating Recollection of Low-Frequency Internal Motions (Phonons) in Biomacromolecules, Voice of Publication (VP), 6 (2020) 164-166.

495. K.C. Chou, The Significant and Profound Impacts of Gordon Life Science Institute Short, Int J Genomics Pro- 
teomics Metabolomics Bioinformatics, 3 (2020) 43-50.

496. K.C. Chou, Applications of graph theory to enzyme kinetics and protein folding kinetics: steady and non-steady state systems (Short Communication), Journal of Sensor Networks and Data Communications, 1 (2020) 06-07.

497. K.C. Chou, Revisiting the paper on "Applications of graph theory to enzyme kinetics and protein folding kinetics: steady and non-steady state systems" (Short Communication), J, Biotechnology and Bioprocessing, 1 (2020) $1-2$.

498. L. Fang, X. Wang, Z. Lai, D. Zhang, M. Wu, Z. Pan, L. Wang, K. Tang, D. Qian, Z. Huang, X. Wang, H. Chen, K.C. Chou, Reveal the molecular principle of coronavirus disease 2019 (COVID-19), Index of Sciences, 12 (2020) 1-13.

499. J. Jia, X. Wei, W. Qiu, K.C. Chou, iSulf_Wide-PseAAC: Predict S-sulfonylation sites in proteins by Wide learning approach Genomics, in press (2020).

500. S. Khan, M. Khan, N. Iqbal, S.A. Khan, K.C. Chou, Prediction of piRNAs and their function based on discriminative intelligent model using hybrid features into Chou's PseKNC, Chemometrics and Intelligent Laboratory (CHEMOLAB), 203 (2020) 104056.

501. Y.D. Khan, N. Amin, W. Hussain, N. Rasool, S.A. Khan, K.C. Chou, iProtease-PseAAC(2L): A two-layer predictor for identifying proteases and their types using Chou's 5-step-rule and general PseAAC, Anal. Biochem., 588 (2020) 113477.

502. W. Lin, X. Xiao, W. Qiu, K.C. Chou, Use Chou's 5-Steps Rule to Predict Remote Homology Proteins by Merging Grey Incidence Analysis and Domain Similarity Analysis, Natural Science, 12 (2020) 181-198.

503. X.X. Liu, K.C. Chou, pLoc_Deep-mGneg: predict subcellular localization of Gram negative bacterial proteins by deep learning Advances in Bioscience and Biotechnology (ABB) 11 (2020) 141-152.

504. Z. Lu, K.C. Chou, Showcase to illustrate how the web-server pLoc_Deep-mGpos is working, Journal of Biomedical cience and Engineering (JBiSE) 13 (2020) 55-65.

505. Z. Lu, K.C. Chou, iATC_Deep-mISF: a multi-label classifier for predicting the classes of anatomical therapeutic chemicals by deep learning, Advances in Bioscience and Biotechnology (ABB) 11 (2020) 153-159.

506. B. Niu, C. Liang, Y. Lu, M. Zhao, Q. Chen, Y. Zhang, L. Zheng, K.C. Chou, Glioma stages prediction based on machine learning algorithm combined with protein-protein ineraction networks, Genomics, 112 (2020) 837-847.

507. G. Pugalenthi, V. Nithya, K.C. Chou, G. Archunan, Nglyc: A random forest method for prediction of N-Glycosylation sites in eukaryotic protein sequence, Protein \& Peptide Letters, 27 (2020) 178-186.

508. Y.H. Shao, K.C. Chou, pLoc_Deep-mVirus: A CNN Model for Predicting Subcellular Localization of Virus Proteins by Deep Learning, Natural Science, 12 (2020) 1-12.

509. Y.T. Shao, K.C. Chou, pLoc_Deep-mEuk: predict subcellular localization of eukaryotic proteins by deep learning Natural Science, 12 (2020) 1-29.

510. Y.T. Shao, K.C. Chou, pLoc_Deep-mAnimal: A Novel Deep CNN-BLSTM Network to Predict Subcellular Localization of Animal Proteins Natural Science, 12 (2020) 281-291.

511. Y.T. Shao, X.X. Liu, Z. Lu, K.C. Chou, pLoc_Deep-mHum: predict subcellular localization of human proteins by deep learning Natural Science, 12 (2020) 526-547.

512. Y.T. Shao, X.X. Liu, Z. Lu, K.C. Chou, pLoc_Deep-mPlant: predict subcellular localization of plant proteins by deep learning Natural Science 12 (2020) 237-247.

513. R. Xu, L. Lei, R. Qin, Z. Huang, K.C. Chou, The topological entropy mechanism of coronavirus disease 2019 (COVID-19), Natural Science, 12 (2020) 737-742.

514. D. Zhang, L. Fang, L. Wang, Z. Pan, Z. Lai, M. Wu, K. Tang, L. Ludan, Q. Dahong, Z. Huang, X. Wang, H. 
Chen, K.C. Chou, The physicochemical mechanism of pestilences or coronavirus disease 2019 (COVID-19), Acad. J. Microbiol. Res., 8 (2020) 049-055.

515. D. Zhang, L. Fang, L. Wang, Z. Pan, Z. Lai, M. Wu, K. Tang, L. Ludan, D. Qian, Z. Huang, X. Wang, H. Chen, K.C. Chou, The Physical Principle of Coronavirus Disease 2019 (COVID-19), Index of Sciences, 12 (2020) 1-13.

516. D. Zhang, L. Fang, L. Wang, Z. Pan, Z. Lai, M. Wu, K. Tang, L. Ludan, D. Qian, Z. Huang, X. Wang, H. Chen, K.C. Chou, The Chemical Mechanism of Pestilences or Coronavirus Disease 2019 (COVID-19), Natural Science, 12 (2020) 717-725.

517. G.P. Zhou, K.C. Chou, Two Latest Hot Researches in Medicinal Chemistry, Current Topics in Medicinal Chemistry, 20 (2020) 1-2.

518. K.C. Chou, The Significant and Profound Impacts of Protein Subcellular Localization Prediction, Voice of Publication (VP), 7 (2021) 2380-7571.

519. K.C. Chou, The Significant and Profound Impacts of Gordon Life Science Institute, Voice of Publication (VP), 7 (2021) 1-26.

520. P.H. Guo, Z. Huang, X. Wang, H. Chen, K.C. Chou, The cellular mechanism of pestilences or coronavirus disease 2019 (COVID-19) Natural Science, 13 (2021) 8-19.

521. K.C. Chou, S. Forsen, Graphical rules for enzyme-catalyzed rate laws, Biochem. J., 187 (1980) 829-835.

522. G.Q. Zhou, W.Z. Zhong, Diffusion-controlled reactions of enzymes. A comparison between Chou's model and Alberty-Hammes-Eigen's model, Eur. J. Biochem., 128 (1982) 383-387.

523. K.C. Chou, H.A. Scheraga, Origin of the right-handed twist of beta-sheets of poly-L-valine chains, Proceedings of the National Academy of Sciences of the United States of America (PNAS USA), 79 (1982) 7047-7051.

524. K.C. Chou, G.M. Maggiora, H.A. Scheraga, The role of loop-helix interactions in stabilizing four-helix bundle proteins, Proceedings of the National Academy of Sciences of the United States of America (PNAS USA), 89 (1992) 7315-7319.

525. X. Du, Y. Diao, H. Liu, S. Li, MsDBP: Exploring DNA-binding Proteins by Integrating Multi-scale Sequence Information via Chou's 5-steps Rule, Journal of Proteome Research, 18 (2019) 3119-3132.

526. A. Dutta, A. Dalmia, A. R, K.K. Singh, A. Anand, Using the Chou's 5-steps rule to predict splice junctions with interpretable bidirectional long short-term memory networks, Comput Biol Med, 116 (2019) 103558.

527. Z. Jun, S.Y. Wang, Identify Lysine Neddylation Sites Using Bi-profile Bayes Feature Extraction via the Chou's 5-steps Rule and General Pseudo Components, Current Genomics, 20 (2019) 592-601.

528. J. Lan, J. Liu, C. Liao, D.J. Merkler, Q. Han, J. Li, A Study for Therapeutic Treatment against Parkinson's Disease via Chou's 5-steps Rule, Current Topics in Medicinal Chemistry, 19 (2019) 2318-2333.

529. R. Liang, J. Xie, C. Zhang, M. Zhang, H. Huang, H. Huo, X. Cao, B. Niu, Identifying Cancer Targets Based on Machine Learning Methods via Chou's 5-steps Rule and General Pseudo Components, Current Topics in Medicnal Chemistry, 19 (2019) 2301-2317.

530. Y. Liang, S. Zhang, Identifying DNase I hypersensitive sites using multi-features fusion and F-score features selection via Chou's 5-steps rule, Biophys Chem, 253 (2019) 106227.

531. A. Wiktorowicz, A. Wit, A. Dziewierz, L. Rzeszutko, D. Dudek, P. Kleczynski, Calcium Pattern Assessment in Patients with Severe Aortic Stenosis Via the Chou's 5-Steps Rule, Current Pharmaceutical Design 25 (2019) 6-31.

532. L. Yang, Y. Lv, S. Wang, Q. Zhang, Y. Pan, D. Su, Q. Lu, Y. Zuo, Identifying FL11 subtype by characterizing tumor immune microenvironment in prostate adenocarcinoma via Chou's 5-steps rule, Genomics, 112 (2019) 1500-1515. 
533. M.A. Akmal, W. Hussain, N. Rasool, Y.D. Khan, S.A. Khan, K.C. Chou, Using Chou's 5-steps rule to predict O-linked serine glycosylation sites by blending position relative features and statistical moment, IEEE/ACM Trans Comput Biol Bioinform, PP (2020).

534. H. Bouziane, A. Chouarfia, Use of Chou's 5-steps rule to predict the subcellular localization of gram-negative and gram-positive bacterial proteins by multi-label learning based on gene ontology annotation and profile alignment, J Integr Bioinform, (2020).

535. P. Charoenkwan, N. Schaduangrat, C. Nantasenamat, T. Piacham, W. Shoombuatong, iQSP: A Sequence-Based Tool for the Prediction and Analysis of Quorum Sensing Peptides via Chou's 5-Steps Rule and Informative Physicochemical Properties, Int. J. Mol. Sci., 21 (2020) 75.

536. P. Charoenkwan, N. Schaduangrat, C. Nantasenamat, T. Piacham, W. Shoombuatong, Correction: Shoombuatong, W., et al. iQSP: A Sequence-Based Tool for the Prediction and Analysis of Quorum Sensing Peptides via Chou's 5-Steps Rule and Informative Physicochemical Properties. Int. J. Mol. Sci. 2020, 21, 75, Int J Mol Sci, 21 (2020).

537. Y. Chen, X. Fan, Use of Chou's 5-Steps Rule to Reveal Active Compound and Mechanism of Shuangshen Pingfei San on Idiopathic Pulmonary Fibrosis, Curr Mol Med, 20 (2020) 220-230.

538. L. Du, Q. Meng, H. Jiang, Y. Li, Using Evolutionary Information and Multi-Label Linear Discriminant Analysis to Predict the Subcellular Location of Multi-Site Bacterial Proteins via Chou's 5-Steps Rule, IEEE Access, 8 (2020) 56452-56461.

539. Z. Ju, S.Y. Wang, Prediction of lysine formylation sites using the composition of k-spaced amino acid pairs via Chou's 5-steps rule and general pseudo components, Genomics, 112 (2020) 859-866.

540. M. Kabir, S. Ahmad, M. Iqbal, M. Hayat, iNR-2L: A two-level sequence-based predictor developed via Chou's 5-steps rule and general PseAAC for identifying nuclear receptors and their families, Genomics, 112 (2020) 276-285.

541. D. Nguyen, T. Ho-Quang, L. Nguyen Quoc Khanh, V. Dinh-Phan, Y.Y. Ou, Use Chou's 5-steps rule with different word embedding types to boost performance of electron transport protein prediction model, IEEE/ACM Trans Comput Biol Bioinform, PP (2020).

542. R.P. Pandey, S. Kumar, S. Ahmad, A. Vibhuti, V.S. Raj, A.K. Verma, P. Sharma, E. Leal, Use Chou's 5-steps rule to evaluate protective efficacy induced by antigenic proteins of Mycobacterium tuberculosis encapsulated in chitosan nanoparticles, Life Sci., 256 (2020) 117961.

543. T. Roy, P. Bhattacharjee, A LabVIEW-based real-time modeling approach via Chou's 5-steps rule for detection of abnormalities in cancer cells, Gene Reports, (2020) 100788.

544. H. Vundavilli, A. Datta, C. Sima, J. Hua, R. Lopes, M. Bittner, Using Chou's 5-steps rule to Model Feedback in Lung Cancer IEEE Journal of Biomedical and Health Informatics, 21 (2020) 1-24.

545. L. Yang, Y. Lv, S. Wang, Q. Zhang, Y. Pan, D. Su, Q. Lu, Y. Zuo, Identifying FL11 subtype by characterizing tumor immune microenvironment in prostate adenocarcinoma via Chou's 5-steps rule, Genomics, 112 (2020) 1500-1515.

546. S. Zhang, T. Xue, Use Chou's 5-steps rule to identify DNase I hypersensitive sites via dinucleotide property matrix and extreme gradient boosting, Molecular genetics and genomics: MGG, (2020).

547. Z. Zhang, L. Wang, Using Chou's 5-steps rule to identify N(6)-methyladenine sites by ensemble learning combined with multiple feature extraction methods, J. Biomol. Struct. Dyn., (2020) 1-11.

548. M. Gerritsen, K.C. Chou, G. Nemethy, H.A. Scheraga, Energetics of multi-helix interactions in protein folding: Application to myoglobin, Biopolymers, 24 (1985) 1271-1291. 